\title{
Mid-latitude freshwater availability reduced by projected vegetation responses to climate change
}

\author{
Justin S. Mankin ${ }^{1,2,3 \star}$, Richard Seager ${ }^{3}{ }^{3}$, Jason E. Smerdon ${ }^{3}$, Benjamin I. Cook ${ }^{3,4}$ and \\ A. Park Williams ${ }^{3}$
}

Plants are expected to generate more global-scale runoff under increasing atmospheric carbon dioxide concentrations through their influence on surface resistance to evapotranspiration. Recent studies using Earth System Models from phase 5 of the Coupled Model Intercomparison Project ostensibly reaffirm this result, further suggesting that plants will ameliorate the dire reductions in water availability projected by other studies that use aridity metrics. Here we complicate this narrative by analysing the change in precipitation partitioning to plants, runoff and storage in multiple Earth system models under both high carbon dioxide concentrations and warming. We show that projected plant responses directly reduce future runoff across vast swaths of North America, Europe and Asia because bulk canopy water demands increase with additional vegetation growth and longer and warmer growing seasons. These runoff declines occur despite increased surface resistance to evapotranspiration and vegetation total water use efficiency, even in regions with increasing or unchanging precipitation. We demonstrate that constraining the large uncertainty in the multimodel ensemble with regional-scale observations of evapotranspiration partitioning strengthens these results. We conclude that terrestrial vegetation plays a large and unresolved role in shaping future regional freshwater availability, one that will not ubiquitously ameliorate future warming-driven surface drying.

T: he future supply and demand of freshwater will be a function of myriad factors: peoples' political, economic, institutional and consumptive choices ${ }^{1}$, the planetary temperature response to such choices ${ }^{2}$, the changing patterns of precipitation and evaporative demand ${ }^{3}$ and the subsequent cascade of biogeophysical and biogeochemical feedbacks and responses ${ }^{4}$. Central to the latter factor is how plants will acclimate to greenhouse gases (GHGs), which cause both longer and warmer growing seasons and amplified photosynthesis (carbon dioxide $\left(\mathrm{CO}_{2}\right)$ fertilization) ${ }^{5}$, leading to changes in ecosystem water consumption and, by extension, the water available in soils and streams.

Since Idso and Brazel ${ }^{6}$, the dominant assessment has been that plants will make the world's land surfaces wetter in the future because plants partially close their stomata in response to high $\mathrm{CO}_{2}$ concentrations $\left(\left[\mathrm{CO}_{2}\right]\right)$, which increases surface resistance to evapotranspiration (ET). All else being equal, plants have the potential to ameliorate hydrological drought risks from warming by increasing soil moisture and streamflow ${ }^{6-10}$ (Extended Data Fig. 1). Idso and Brazel's 'plants turn on the tap ${ }^{11}$ result has re-emerged recently with more sophisticated models and constraints ${ }^{8-10,12,13}$, often cast as stark contrasts to projections of widespread aridity increases using metrics based, in part, on potential evapotranspiration (PET) ${ }^{14-16}$. Aridity metrics using PET assume stationary surface resistance to ET and thus potentially overstate warming-induced drying ${ }^{8,13}$. However, despite missing a fundamental physiological response of plants to high $\left[\mathrm{CO}_{2}\right]$, aridity projections using PET are remarkably consistent with prognostic soil moisture projections of Earth system models $(\mathrm{ESMs})^{17,18}$. This consistency suggests that while there are good reasons to question the appropriateness of PET-based metrics for assessments of aridity changes under warming, there may also be good reasons to question whether plants represent a panacea for freshwater availability under warming. While large-scale experiments ${ }^{19}$ (Supplementary Table 1) and observations ${ }^{20,21}$ are consistent with plants increasing land water availability, there is some evidence in experiments ${ }^{22,23}$, observation ${ }^{24-29}$ and models ${ }^{30,31}$ suggesting that the combined effects of $\mathrm{CO}_{2}$ fertilization and longer and warmer growing seasons can increase ecosystem water use for some regions, outpacing decreases in transpiration from high $\left[\mathrm{CO}_{2}\right]$.

The suggestion that plant responses to increased $\left[\mathrm{CO}_{2}\right]$ will ameliorate surface drying does not capture the scope of regionalscale hydrological responses in the models from phase 5 of the Coupled Model Intercomparison Project (CMIP5). In CMIP5, plants do increase surface resistance to ET by the end of this century (Fig. 1a), but they also consume more water relative to the late twentieth century across $67 \%$ of the land surface in the ensemble mean (Fig. 1b). There are few regions where ecosystem water consumption significantly declines across the ensemble (brown unhatched areas in Fig. $1 \mathrm{~b}$ and Methods). Some $\sim 62 \%$ of continental land areas have projected summer soil moisture declines (Fig. 1c), regardless of the regional surface resistance increases (Fig. 1a). For some of these regions, soil moisture declines are associated with significantly reduced water-year (WY) runoff (Fig. 1d and Methods) and either increased or highly uncertain WY canopy water fluxes (hatched areas in Fig. 1b). Such declines occur even though these regions have modest increases in WY precipitation in the ensemble mean (Extended Data Fig. 2a) because they are associated with robustly increasing leaf area index (LAI) (Extended Data Fig. 2b). Consequently, there is little evidence across the CMIP5 ensemble for plants acting to exclusively reduce future warming-driven aridity at regional scales because of regional differences in how vegetation alters the partitioning of precipitation at the land surface.

\footnotetext{
'Department of Geography, Dartmouth College, Hanover, NH, USA. ²Department of Earth Sciences, Dartmouth College, Hanover, NH, USA. ${ }^{3}$ Lamont-Doherty Earth Observatory of Columbia University, Palisades, NY, USA. ${ }^{4}$ NASA Goddard Institute for Space Studies, New York, NY, USA. *e-mail: mankin@dartmouth.edu
} 


\section{Projected changes in precipitation partitioning}

Precipitation input at the surface must be balanced by its partitioning to runoff $(Q)$, vegetation canopies (the sum of transpiration and interception, $C$ ), and soils and long-term storage (soil+ storage, $S$ ) (Extended Data Fig. 1a). If plant responses to increased $\left[\mathrm{CO}_{2}\right]$ expand land-surface water availability through stomatal closure, then the fraction of precipitation partitioned to the canopy $(C / P)$ should decrease (assuming no change in precipitation) while partitioning to runoff $(Q / P)$ and soil+storage $(S / P)$ should increase (Extended Data Fig. 1b). By contrast, if $C / P$ increases from longer and warmer growing seasons and $\mathrm{CO}_{2}$ fertilization, this will diminish $Q / P$ and $S / P$ (Extended Data Fig. 1c).

To identify where vegetation in the CMIP5 projections siphons precipitation that historically would have been partitioned to runoff, and to quantify the magnitude of that future potential runoff loss, we use a previously developed metric called the blue-water tradeoff $^{31}$ (BWT) (Methods). BWT quantifies the magnitude of the relative change in precipitation partitioning between plants and streamflow. This is not the same as changes in either canopy or runoff partitioning but instead represents precipitation partitioning changes solely between canopies and runoff. BWT renders (in units of runoff) the explicit trading of water between vegetation and streamflow under forcing, providing an immediate picture of where vegetation is consistent or inconsistent with the 'plants turn on the tap' global picture. BWT does not reveal the pathway by which plants increase their relative consumption of water (for example, decreased precipitation, increased leaf area, unchanging water use efficiency, longer growing season); as such, the metric represents a starting point for our analysis.

The spatial pattern of BWT (Fig. 2a) shows vast continental swaths where vegetation is consistent (blue) or inconsistent (brown) with the 'plants turn on the tap' global-scale response. Positive (brown) values represent the amount of potential WY runoff lost to future vegetation on the basis of projected changes in relative partitioning, while negative (blue) values show the opposite. The tropics generally show a relative increase of $20 \mathrm{~mm}$ or more in precipitation partitioning to runoff and away from plants (Fig. 2a), equivalent to $\sim 12 \%$ of historical WY runoff (Extended Data Fig. 3). Two factors account for this. First, the marginal increase in transpiration as a fraction of ET (T/ET) declines as a function of $\mathrm{LAI}^{32}$. In the tropics, where LAI is already high and where its projected changes are uncertain (Extended Data Fig. 2b), there is little transpiration gain (and little WY canopy water flux increase) from additional canopies, irrespective of stomatal closure (Fig. 1a). Second, projected increases in tropical extreme precipitation ${ }^{33}$ would be associated with enhanced canopy drip (tropical canopies are near leaf saturation) and thus, given the structure of model parametrizations, additional saturation and infiltration-excess runoff at the land surface $^{31}$. By contrast, most of North America and Eurasia show the opposite effect. Future canopies increase the relative fraction of precipitation they consume, equivalent to more than $20 \mathrm{~mm}$ per WY of potential runoff lost for parts of those regions (Fig. 2a and Extended Data Figs. 3 and 6). Thus, to the extent plants make the world wetter under high $\left[\mathrm{CO}_{2}\right]$, this is driven almost entirely by the tropics, which generally have high water availability already, or the very high latitudes, where human water demands are generally low.

It is clear that future canopies in the populous mid-latitudeseven in the presence of significantly increased canopy water use efficiency (WUE), canopy resistance (Fig. 1a) and precipitation (Extended Data Fig. 2a) - can demand more of incoming precipitation at the direct sacrifice of runoff. What accounts for these partitioning changes in the models and what does it imply about future water availability at the land surface? To answer this, we examine regional responses, focusing on two regions with clear BWT increases (North America and Eurasia) (Fig. 2b,f and Extended Data Fig. 6) and three with uncertain or modest changes (Amazon,
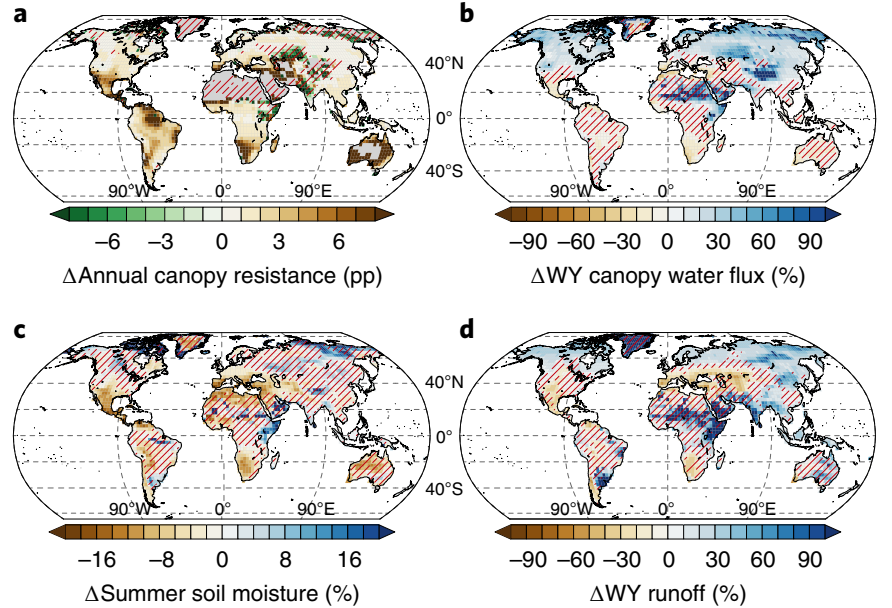

Fig. 1 | Vegetation and water availability projections. a, End-of-century percentage point (pp) change (2070-2099 minus 1976-2005) in annual bulk canopy resistance, estimated as the ratio of the annual vapour pressure deficit to the bulk canopy water flux for 16 CMIP5 models in RCP8.5. b, End-of-century percentage (\%) change in WY canopy water flux (transpiration plus leaf evaporation). c, End-of-century percentage (\%) change in full-column summer (June-August in the Northern Hemisphere; December-February in the Southern Hemisphere) soil moisture. d, End-ofcentury percentage (\%) change in WY total runoff. Red hatching covers regions with insignificant change on the basis of a Kolmogorov-Smirnov test of the pooled model-year distribution for the historical period (19762005 ) versus the future period (2070-2099) and at least $80 \%$ of the models agreeing on the direction of mean change at that point (Methods).

South Africa and Australia) (Fig. 2c-e). For each region, we present four panels in Fig. 2: the time series of regional-average percentage change in WUE and LAI (first panel), the time series of percentage point change in regional-average precipitation partitioning ratios (second panel), the historical partitioning ratios (bar plot) and the model-by-model percentage point changes in the partitioning ratios (scatter plot) (Fig. 2b-f).

Despite considerable model- and region-specific precipitation partitioning responses (Fig. $2 \mathrm{~b}-\mathrm{f}$ ), several general features are apparent. First, all regions have significantly increasing ensemble mean WUE because higher $\left[\mathrm{CO}_{2}\right]$ allows plants to fix carbon at a lower water cost (Fig. $2 \mathrm{~b}-\mathrm{f}$, top panels). At the same time, canopy densities increase nearly ubiquitously (Fig. $2 b-f$, top panels, and Extended Data Fig. 2b), though only North America (Fig. 2b) and Eurasia (Fig. 2f) show significant regional LAI increases (bolded lines) (Methods). Second, canopy partitioning is the dominant term across regions and models (Fig. $2 \mathrm{~b}-\mathrm{f}$, bar plots). Third, the changes in canopy partitioning and runoff partitioning are significantly inversely related across the ensemble (Spearman's $\rho=-0.57$ ); canopy partitioning is also significantly inversely related to soil + storage partitioning across models and regions (Spearman's $\rho=-0.53$ ) as interception, a key component of canopy partitioning, is physically upstream of water entering the soil column (Fig. 2b-f, scatter plots). The relationship between changes in runoff and soil + storage partitioning is weaker, but significant (Spearman's $\rho=-0.30$ ), highlighting that canopy partitioning exerts a control on both. This is expected because canopy partitioning opposes both runoff and soil+ storage partitioning: canopy partitioning correlates negatively to precipitation and positively to temperature (Extended Data Fig. 5). Finally, despite this inversely related structure among all partitioning terms, there is also a high degree of model uncertainty in simulating changes in land-surface partitioning of precipitation, denoted by the varied responses among models within regions (Fig. $2 b-f$, 
b
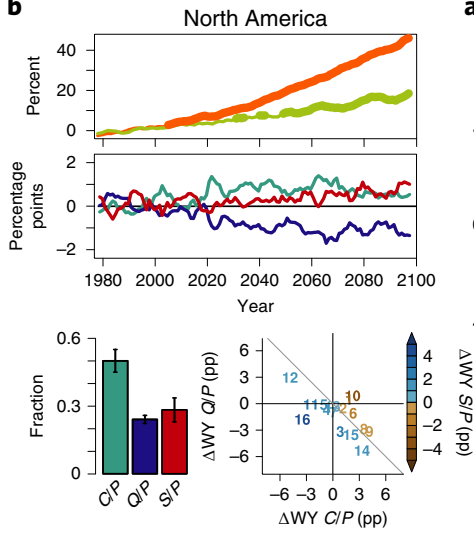

a

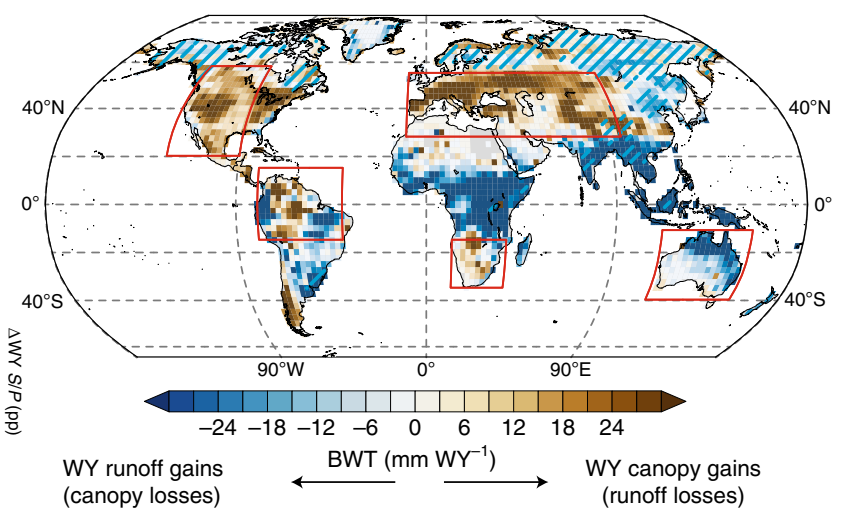

f

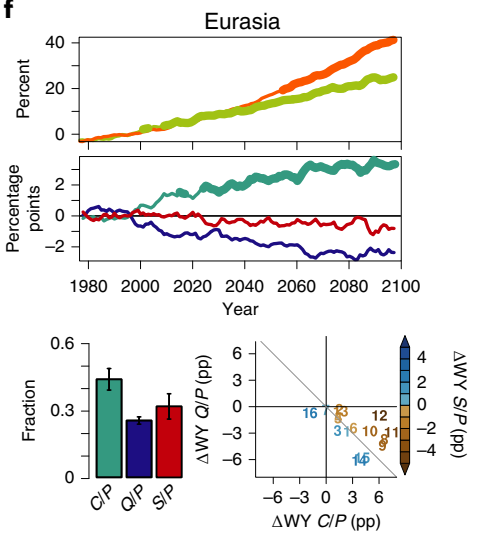

$$
\begin{array}{r}
\text { WUE } \\
\text { LAI } \\
\text { C } / P \\
\text { QIP } \\
S / P
\end{array}
$$

1: bcc-csm1-1-m

2: bcc-csm1-1

3: CanESM

4: CCSM4

6: CESM1-CAM5

7: CESM1-WACCM

8: GFDL-ESM2

9: GFDL-ESM2M

10: inmcm4

11: IPSL-CM5A-LR

12: IPSL-CM5A-MR

13: IPSL-CM5B-LR

14: MIROC-ESM-CHEM

15: MIROC-ESM

16: NorESM1-ME c
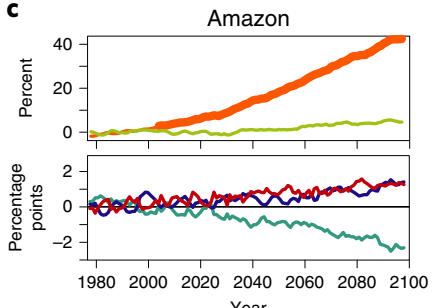

Year

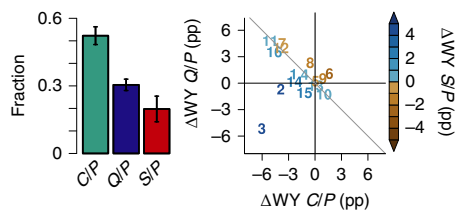

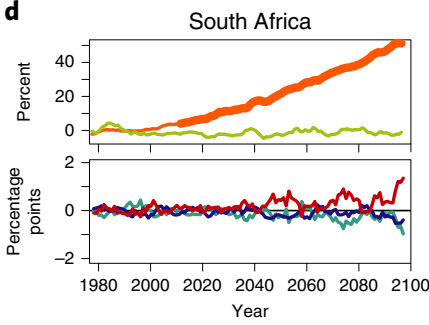
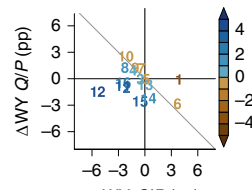

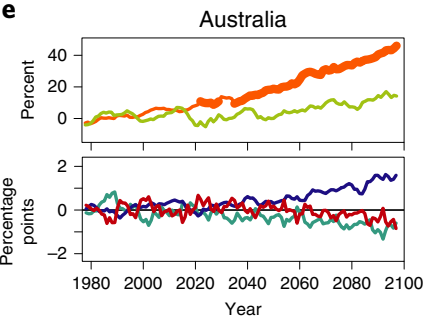

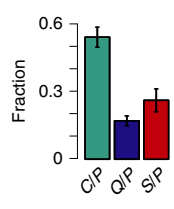

$\triangle \mathrm{WY} C / P(\mathrm{pp})$
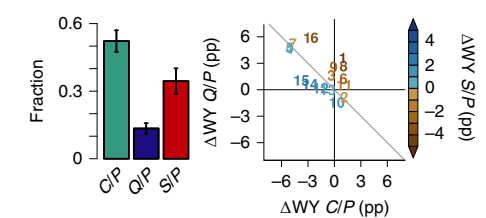

Fig. 2 | Relative changes in the hydrological budget at the land surface. Lettering of panels goes anticlockwise from centre map. a, For 16 CMIP5 models in RCP8.5, a map of the end-of-century BWT (Methods). Brown colours signify the amount of WY precipitation that goes to the future canopy and directly away from runoff; blue colours signify the opposite. Light-blue hatching covers regions where the ensemble predicts significant increases in WY runoff. For each of five highlighted regions $\mathbf{b}-\mathbf{f}$ (red outlined regions in $\mathbf{a}$ ), there are four panels, from top to bottom: (1) First panel: the annual percentage (\%) changes in LAI (light green) and bulk WUE (GPP/transpiration, orange). (2) Second panel: the WY anomalies of canopy partitioning (C/P, green), runoff partitioning $(Q / P$, blue $)$ and soil + storage partitioning $(S / P$, red) as percentage point ( $p p)$ change. Bolded lines in the first and second panels signify signal emergence of the ensemble mean $\mu$ above the noise $\sigma$ as $\mu / \sigma>1$ in that year from the baseline (1976-2005). (3) Bar plot: the historical ensemble mean fraction of WY precipitation partitioned to the canopy $(C / P)$, runoff $(Q / O)$ and soil + storage $(S / P)$. Whiskers show 1 s.d. of the ensemble variability. $(4)$ Scatter plot: the ensemble spread in the change in WY precipitation partitioning to the canopy ( $x$ axis), runoff ( $y$ axis) and soil + storage (colours) all in percentage points (pp).

scatter plots). Such uncertainty in partitioning responses across models within regions, as well as unclear experimental evidence about hydrological responses to $\mathrm{CO}_{2}$ enrichment in absence of warming (Supplementary Table 1), only reinforces questions about the generalizability of plants making the world wetter in a warmer, $\mathrm{CO}_{2}$-enriched world.

The two regions with the clearest future potential runoff losses to the canopy, North America and Eurasia (Fig. 2a and Extended Data Fig. $6 \mathrm{a}, \mathrm{c})$, both have declining runoff partitioning and increasing canopy partitioning (Fig. 2b,f, second panels). In North America, decline in the former is associated with modest increases in the latter, along with increased soil + storage partitioning (Fig. 2b). By contrast, both runoff and soil + storage decrease in Eurasia, where LAI increases (Fig. 2f) are most clearly associated with increased canopy partitioning. South Africa shows an alternative path to increased BWT: WY precipitation declines (Fig. 3d and Extended Data Fig. 2a) lead to increased dryland partitioning to soil+storage (Fig. 2d, second panel). In the Amazon and Australia, precipitation changes are large but highly uncertain across the ensemble, making mean precipitation changes quite small (Fig. 3b,e and Extended Data Fig. 2a). Both regions experience increased runoff partitioning (Fig. 2c,e, second panel), leading to insignificant increases in runoff (Fig. 3b,e). Increased runoff partitioning in the Amazon and
Australia is consistent with increased surface resistance to ET (Fig. 1a), and thus water at the land surface, both related to relative changes in LAI. In the Amazon, relative and absolute changes in LAI are small (Fig. 2c, top panel, and Extended Data Fig. 2b), allowing increases in surface resistance to outpace additional canopy water demands from LAI increases (Fig. 1a,c). In Australia, relative LAI changes are large (Fig. 2e, top panel), but absolute LAI is very low. Thus, any increased canopy water demands from additional vegetation growth in Australia are compensated by the modest increases in precipitation (Fig. 3e and Extended Data Fig. 2a) and surface resistance (Fig. 1a).

\section{Runoff declines from increased vegetation water demand}

Projected changes presented in Fig. 2a and Extended Data Fig. 6 are estimated on the basis of relative changes in precipitation partitioning among runoff and vegetation; but precipitation is also changing-increasing in many regions (Extended Data Fig. 2a) - begging the question of whether such relative changes in precipitation partitioning matter for absolute changes in water availability. We show that BWT and changes in canopy partitioning, which are relative measures, are closely associated with absolute changes in total WY runoff, canopy water flux and soil+storage (Fig. 3). Models and regions with positive BWT exhibit a similar pattern across regions, 

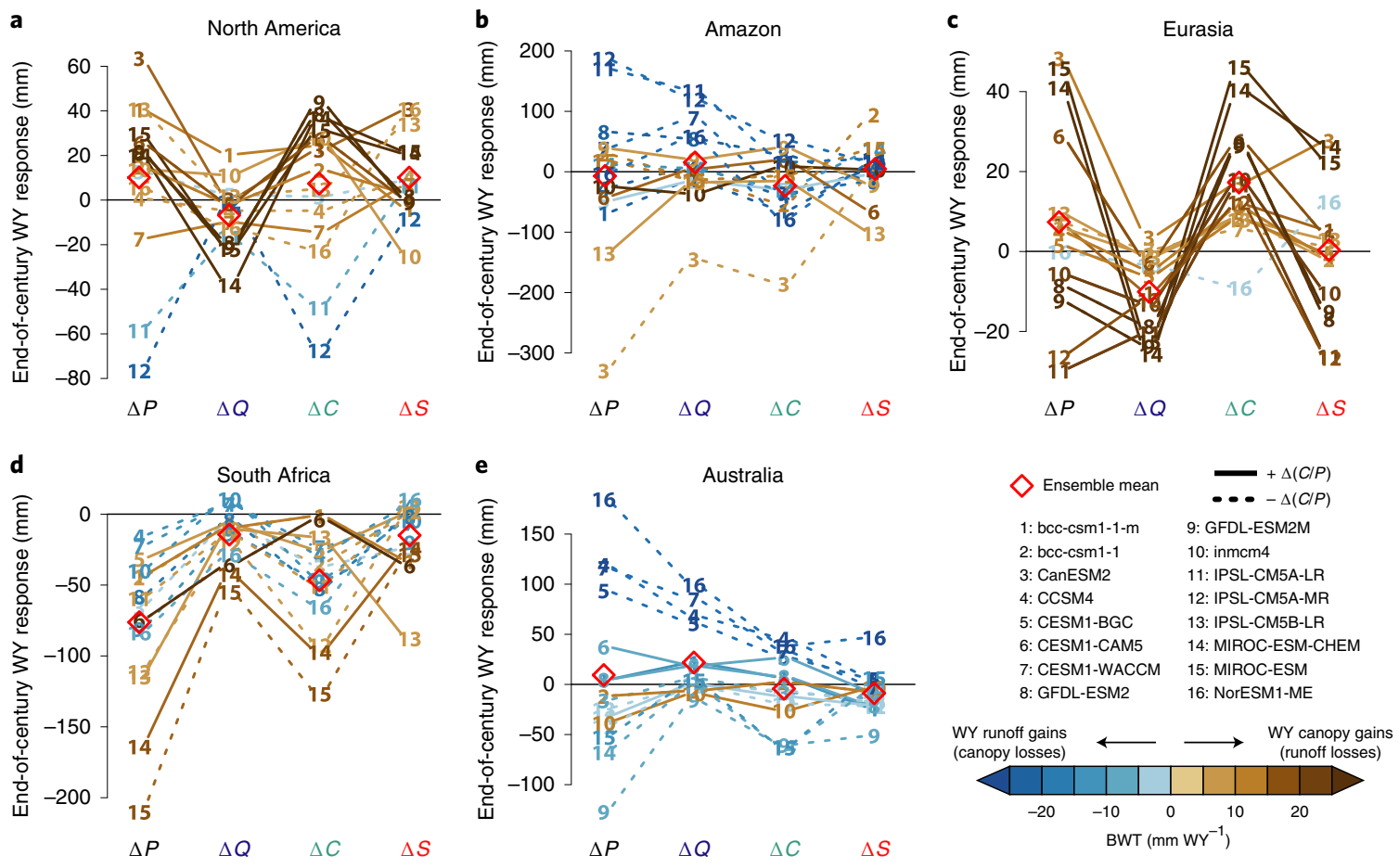

Fig. 3 Absolute changes in the hydrological budget at the land surface. a-e, End-of-century WY response of precipitation $(P)$, runoff (Q), canopy water flux (C), and soil + storage (S) for each of the 16 CMIP5 models for North America (a), Amazon (b), Eurasia (c), South Africa (d) and Australia (e). Model and line colours signify BWT (Methods). Red diamonds show the ensemble mean response. Solid lines show models with increases in canopy partitioning, $C / P$, siphoning precipitation away from either $Q$ or $S$; dotted lines show the opposite.

with bulk decreases in WY runoff, increases in WY canopy water flux and decreases in (or stationary) WY soil+ storage (a down, up, down pattern seen in Fig. 3a,c).

The diversity of bulk changes in WY runoff across models and regions can be skilfully accounted for by relative changes in partitioning to the canopy and runoff alone (Fig. 4): increased BWT is associated with WY runoff declines, explaining $~ 64 \%$ (adjusted $R^{2}$ ) of the intermodel and regional variance in all runoff changes (Fig. 4a). The strength of the association between BWT and runoff changes is similar to that between precipitation and runoff changes (or temperature and runoff changes) (Extended Data Fig. 7a). This implies that, within models, the change in the relative partitioning of precipitation to vegetation is as important as changes in precipitation or temperature in accounting for centennial-scale runoff change. When these three terms are combined into a single empirical model (BWT, precipitation change and temperature change), approximately $94 \%$ of the variance in each model and region's runoff changes can be collectively accounted for (Extended Data Fig. 7b). This remarkable result emphasizes two things. First, while direct plant physiological responses to high $\left[\mathrm{CO}_{2}\right]$ suggest a wetter land surface ${ }^{9,13}$, the combined biogeophysical effects of high $\left[\mathrm{CO}_{2}\right]$ on plants (longer and warmer growing seasons, additional LAI, WUE increases and stomatal conductance decreases) result in an overall drier land surface for vast regions already plagued with water stress. Second, while runoff in the global mean may increase due to aggregate plant responses to $\left[\mathrm{CO}_{2}\right]$, this is driven primarily by the already wet tropics and low-water-demand high latitudes, obfuscating the vast continental regions where plant responses reduce water availability at the land surface even in the face of increasing precipitation.

Thus, increased canopy partitioning of precipitation from additional vegetation and warmer and longer growing seasons-despite increased precipitation (Fig. 3 and Extended Data Fig. 2a), WUE (Fig. 2b-f, top panels) and surface resistance to ET (Fig. 1a) -is a crucial driver of centennial-scale forced runoff declines across the densely populated mid-latitudes. Therefore, while plants are projected to mitigate surface drying in some regions through physiological responses to high $\left[\mathrm{CO}_{2}\right]$, other regions exhibit total plant responses that decrease water in soils and streams ${ }^{30,31}$.

\section{Observationally constraining vegetation-runoff tradeoffs}

Despite the preceding characterizations of the CMIP5, the model heterogeneity in precipitation partitioning suggests a pervasive structural uncertainty across the ensemble, raising questions about the trustworthiness of such projections. For example, there are significant model biases in transpiration, and correcting the CMIP5 ensemble for T/ET biases leads to a further increase in projected global runoff relative to an uncorrected ensemble ${ }^{12}$. Model biases in the canopy fraction of ET ( $C / E T)$ would also affect ensemble estimates of BWT and, by extension, runoff changes. While interannual variation in canopy partitioning is governed by precipitation and temperature variability within regions and models (Extended Data Fig. 4), future canopy partitioning is strongly associated with the historical fraction of ET going to the canopy (C/ET) (Extended Data Fig. 8). Projected changes in $C / E T$ strongly correspond to changes in LAI across models and regions (Spearman's $\rho=0.63$ ); thus model and region biases in $C /$ ET may bias projections of canopy partitioning and, by extension, the vegetation-forced runoff declines we identify. Using recent (1982-2014) observations of C/ET (ref. ${ }^{32}$ ) as a constraint on the ensemble range in both BWT and runoff changes (Methods), the preceding results are in fact strengthened. There is a modest reduction in runoff increases in the Amazon and Australia and a deepening of runoff losses in North America, Eurasia and South Africa, all consistent with the BWT responses (Extended Data Fig. 9).

While vegetation-induced hydrological changes from increased $\left[\mathrm{CO}_{2}\right]$ are being documented observationally ${ }^{20,24,29}$, the forcing to date remains low, making robust assessments about regional 

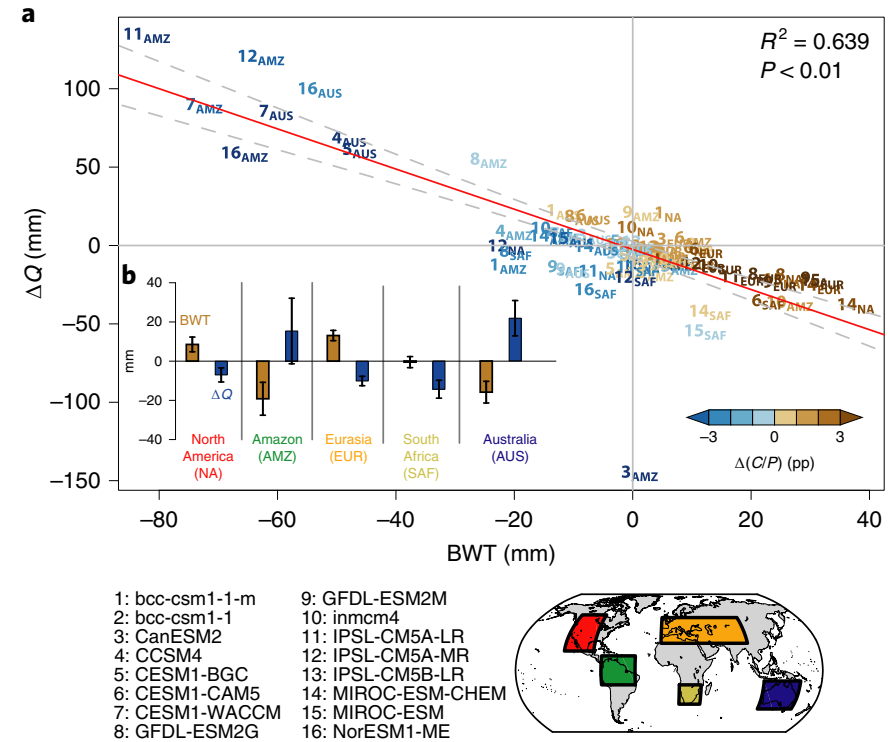

Fig. 4 | The relationship between relative and absolute hydrological changes. a, BWT versus $\Delta Q$ for each model and region (see map and model list). Model numbers are coloured by their change in canopy partitioning $(C / P$, see colour bar, bottom right). Regression line and $95 \%$ confidence interval are shown in red and grey, respectively, along with the adjusted $R^{2}$ and $P$ value. $\mathbf{b}$, Inset bar plot shows the ensemble mean BWT (brown) and runoff change (blue) for each region, with whiskers showing an estimate of the standard error of the mean.

changes difficult. It is therefore useful to compare the modelled effects of $\mathrm{CO}_{2}$ and warming from the CMIP5 on vegetation with the Free-Air Carbon Dioxide Enrichment (FACE) experiments, which are now in their second generation ${ }^{34,35}$ (Supplementary Table 1). Consistent with the previous literature, the results from this comparison are mixed and do not support confidence in or rejection of the CMIP5 projections: $\mathrm{CO}_{2}$ enrichment alone increases water availability at the land surface at numerous FACE sites, but not uniformly so, despite the absence of warming as part of many FACE experimental designs (Supplementary Table 1). Data-model comparisons with FACE experiments are challenging to implement given the vast differences in experimental protocols among sites ${ }^{35,36}$, and are particularly so with fully coupled transient centennial-scale simulations, such as those presented here. This challenge points to the crucial importance of coordinated efforts such as FACE modeldata synthesis (FACE-MDS) ${ }^{36-39}$, which use offline simulations to inform us on how best to evaluate transient responses in the fully coupled ESMs and whether ecosystems will enhance or diminish land-surface water availability.

\section{Plants are crucial to freshwater availability projections}

As land-surface components of ESMs add richer treatments of biogeophysical and biogeochemical processes, it is increasingly clear that structural model choices-in particular, assumptions about plants and their response to increasing $\left[\mathrm{CO}_{2}\right]$-have a large influence over how modelled climate-scale terrestrial water availability changes in the future ${ }^{30,40-43}$. We demonstrate that for vast continental regions with large populations demanding water, the latest generation of models project that total vegetation water demand will increase with warming, regardless of the increased surface resistance to ET from stomatal closure, which has long been painted as a panacea for predicted continental drying from aridity metrics using PET. Closer examination of the models shows that while global runoff may increase and that direct plant physiology will play a part in that, this is primarily a tropical response, where plant water consumption is already high. By contrast, most of highly populated North America, Europe and Asia have projected increases in canopy water consumption that are associated with absolute runoff declines, which would leave less available freshwater for people and riparian ecosystems. As such, it is vital to continue to better understand how plants will affect water availability in the future.

\section{Online content}

Any methods, additional references, Nature Research reporting summaries, source data, extended data, supplementary information, acknowledgements, peer review information; details of author contributions and competing interests; and statements of data and code availability are available at https://doi.org/10.1038/s41561019-0480-x.

Received: 9 May 2019; Accepted: 30 September 2019;

Published online: 04 November 2019

\section{References}

1. Kallis, G., Kiparsky, M., Milman, A. \& Ray, I. Glossing over the complexity of water. Science 314, 1387 (2006).

2. Taylor, K. E. \& Penner, J. E. Response of the climate system to atmospheric aerosols and greenhouse gases. Nature 369, 734-737 (1994).

3. Seager, R., Naik, N. \& Vecchi, G. A. Thermodynamic and dynamic mechanisms for large-scale changes in the hydrological cycle in response to global warming. J. Clim. 23, 4651-4668 (2010).

4. Ciais, P. et al. in Climate Change 2013: The Physical Science Basis (eds Stocker, T. F. et al.) Ch. 6 (IPCC, Cambridge Univ. Press, 2013).

5. Field, C. B., Jackson, R. B. \& Mooney, H. A. Stomatal responses to increased $\mathrm{CO}_{2}$ : implications from the plant to the global scale. Plant Cell Environ. 18, 1214-1225 (1995)

6. Idso, S. B. \& Brazel, A. J. Rising atmospheric carbon dioxide concentrations may increase streamflow. Nature 312, 51-53 (1984).

7. Betts, R. A. et al. Projected increase in continental runoff due to plant responses to increasing carbon dioxide. Nature 448, 1037-1041 (2007).

8. Milly, P. C. D. \& Dunne, K. A. Potential evapotranspiration and continental drying. Nat. Clim. Change 6, 946-949 (2016).

9. Swann, A. L. S., Hoffman, F. M., Koven, C. D. \& Randerson, J. T. Plant responses to increasing $\mathrm{CO}_{2}$ reduce estimates of climate impacts on drought severity. Proc. Natl Acad. Sci. USA 113, 10019-10024 (2016).

10. Roderick, M. L., Greve, P. \& Farquhar, G. D. On the assessment of aridity with changes in atmospheric $\mathrm{CO}_{2}$. Water Resour. Res. 51, 5450-5463 (2015).

11. Jasechko, S. Plants turn on the tap. Nat. Clim. Change 8, 562-563 (2018).

12. Lian, X. et al. Partitioning global land evapotranspiration using CMIP5 models constrained by observations. Nat. Clim. Change 8, 640-646 (2018).

13. Yang, Y., Roderick, M. L., Zhang, S., McVicar, T. R. \& Donohue, R. J. Hydrologic implications of vegetation response to elevated $\mathrm{CO}_{2}$ in climate projections. Nat. Clim. Change 9, 44-49 (2019).

14. Cook, B. I., Smerdon, J. E., Seager, R. \& Coats, S. Global warming and 21st century drying. Clim. Dyn. 43, 2607-2627 (2014).

15. Dai, A. Increasing drought under global warming in observations and models. Nat. Clim. Change 3, 52-58 (2013).

16. Huang, J., Yu, H., Dai, A., Wei, Y. \& Kang, L. Drylands face potential threat under $2^{\circ} \mathrm{C}$ global warming target. Nat. Clim. Change 7, 417-422 (2017).

17. Cook, B. I., Ault, T. R. \& Smerdon, J. E. Unprecedented 21st century drought risk in the American Southwest and Central Plains. Sci. Adv. 1, e1400082 (2015).

18. Ault, T. R., Mankin, J. S., Cook, B. I. \& Smerdon, J. E. Relative impacts of mitigation, temperature, and precipitation on 21 st-century megadrought risk in the American Southwest. Sci. Adv. 2, e1600873 (2016).

19. Ward, E. J. et al. Evapotranspiration and water yield of a pine-broadleaf forest are not altered by long-term atmospheric $\left[\mathrm{CO}_{2}\right]$ enrichment under native or enhanced soil fertility. Glob. Change Biol. 24, 4841-4856 (2018).

20. Cheng, L. et al. Recent increases in terrestrial carbon uptake at little cost to the water cycle. Nat. Commun. 8, 110 (2017).

21. Van Der Sleen, P. et al. No growth stimulation of tropical trees by 150 years of $\mathrm{CO}_{2}$ fertilization but water-use efficiency increased. Nat. Geosci. 8, 24-28 (2015).

22. Nowak, R. S. et al. Elevated atmospheric $\mathrm{CO}_{2}$ does not conserve soil water in the Mojave Desert. Ecology 85, 93-99 (2004).

23. Evans, R. D. et al. Greater ecosystem carbon in the Mojave Desert after ten years exposure to elevated $\mathrm{CO}_{2}$. Nat. Clim. Change 4, 394-397 (2014).

24. Ukkola, A. M. et al. Reduced streamflow in water-stressed climates consistent with $\mathrm{CO}_{2}$ effects on vegetation. Nat. Clim. Change 6, 75-78 (2016). 
25. Frank, D. C. et al. Water-use efficiency and transpiration across European forests during the Anthropocene. Nat. Clim. Change 5, 579-583 (2015).

26. Keenan, T. F. \& Riley, W. J. Greening of the land surface in the world's cold regions consistent with recent warming. Nat. Clim. Change 8, 825-829 (2018).

27. Jiang, L. et al. Scale-dependent performance of CMIP5 earth system models in simulating terrestrial vegetation carbon. J. Clim. 28, 5217-5232 (2015).

28. Zhang, K. et al. Vegetation greening and climate change promote multidecadal rises of global land evapotranspiration. Sci. Rep. 5, 15956 (2015)

29. Trancoso, R., Larsen, J. R., McVicar, T. R., Phinn, S. R. \& McAlpine, C. A. $\mathrm{CO}_{2}$-vegetation feedbacks and other climate changes implicated in reducing base flow. Geophys. Res. Lett. 44, 2310-2318 (2017).

30. Mankin, J. S., Smerdon, J. E., Cook, B. I., Williams, A. P. \& Seager, R. The curious case of projected twenty-first-century drying but greening in the American West. J. Clim. 30, 8689-8710 (2017)

31. Mankin, J. S. et al. Blue water trade-offs with ecosystems in a $\mathrm{CO}_{2}$-enriched climate. Geophys. Res. Lett. 45, 3115-3125 (2018).

32. Wei, Z. et al. Revisiting the contribution of transpiration to global terrestrial evapotranspiration. Geophys. Res. Lett. 44, 2792-2801 (2017).

33. O'Gorman, P. A. Precipitation extremes under climate change. Curr. Clim. Change Rep. 1, 49-59 (2015).

34. Norby, R. J. \& Zak, D. R. Ecological lessons from free-air $\mathrm{CO}_{2}$ enrichment (FACE) experiments. Annu. Rev. Ecol. Evol. Syst. 42, 181-203 (2011).

35. Norby, R. J. et al. Model-data synthesis for the next generation of forest free-air $\mathrm{CO}_{2}$ enrichment (FACE) experiments. New Phytol. 209, 17-28 (2016).

36. Medlyn, B. E. et al. Using ecosystem experiments to improve vegetation models. Nat. Clim. Change 5, 528-534 (2015).
37. Walker, A. P. et al. Comprehensive ecosystem model-data synthesis using multiple data sets at two temperate forest free-air $\mathrm{CO}_{2}$ enrichment experiments: model performance at ambient $\mathrm{CO}_{2}$ concentration. J. Geophys. Res. Biogeosci. 119, 937-964 (2014).

38. De Kauwe, M. G. et al. Forest water use and water use efficiency at elevated $\mathrm{CO}_{2}$ : a model-data intercomparison at two contrasting temperate forest FACE sites. Glob. Change Biol. 19, 1759-1779 (2013).

39. Calfapietra, C. et al. Challenges in elevated $\mathrm{CO}_{2}$ experiments on forests. Trends Plant Sci. 15, 5-10 (2010).

40. Skinner, C. B., Poulsen, C. J. \& Mankin, J. S. Amplification of heat extremes by plant $\mathrm{CO}_{2}$ physiological forcing. Nat. Commun. 9, 1094 (2018)

41. Trugman, A. T., Medvigy, D., Mankin, J. S. \& Anderegg, W. R. L. L. Soil moisture stress as a major driver of carbon cycle uncertainty. Geophys. Res. Lett. 45, 6495-6503 (2018).

42. Kolby Smith, W. et al. Large divergence of satellite and Earth system model estimates of global terrestrial $\mathrm{CO}_{2}$ fertilization. Nat. Clim. Change 6, 306-310 (2016)

43. Kovenock, M. \& Swann, A. L. S. Leaf trait acclimation amplifies simulated climate warming in response to elevated carbon dioxide. Glob. Biogeochem. Cycles 32, 1437-1448 (2018).

Publisher's note Springer Nature remains neutral with regard to jurisdictional claims in published maps and institutional affiliations.

(C) The Author(s), under exclusive licence to Springer Nature Limited 2019 


\section{Methods}

Climate model data. We use 16 models that archived the necessary output for our analysis (see Fig. 2 inset for model list) from CMIP $5^{44}$, all run in the historical and representative concentration pathway (RCP) 8.5 forcing pathways ${ }^{45}$. We use monthly scale outputs interpolated to a common $2.5^{\circ} \times 2.5^{\circ}$ grid via the patch recovery method ${ }^{46}$ of the following variables: (1) precipitation, 'pr'; (2) evapotranspiration, 'evspsbl'; (3) transpiration, 'tran'; (4) leaf evaporation, 'evspsblveg'; (5) soil evaporation, 'evspsblsoi'; (6) leaf area index, 'lai'; (7) total-column soil moisture, 'mrso'; (8) total runoff, 'mrro'; (9) gross primary productivity, 'gpp'; (10) surface air temperature, 'tas'. These data are available for download from the Earth System Grid Federation (ESGF). We analyse totalcolumn soil moisture to maximize the number of models included in the study. Because the models have varying depths of active soil hydrology, we examine total-column soil moisture as percentage changes relative to the historical climate, following ref. ${ }^{47}$

Analysis. We analyse climatological WY totals in $P, C$ (transpiration and leaf evaporation $)^{30}$, ET and $Q$. WY totals are the sum of monthly fluxes (converted to millimetres) during October-September in the Northern Hemisphere and March-February in the Southern Hemisphere. Our definition of WY at the hemispheric scales follows refs. ${ }^{31,48}$, though it can miss some regional differences in the timing of dry season termination. Because models vary considerably in their representations of seasonal hydrology, a hemispheric definition ensures a hydrologically meaningful temporal aggregation without the need for modeland region-specific definitions of WYs. The future response is taken as the difference between the end-of-century (2070-2099) climatology and that for the late twentieth century (1976-2005). Soil moisture is analysed during the summer season, taken as June-August in the Northern Hemisphere and DecemberFebruary in the Southern Hemisphere.

We calculate WUE, a measure of the water cost of carbon assimilation, as the ratio of annual average 'gpp' to 'tran'. Vapour pressure deficit (VPD) is calculated as saturation vapour pressure at the surface air temperature minus actual vapour pressure. Canopy resistance is estimated as the inverse of canopy conductance following Mankin et al. ${ }^{31}$, who used the Community Land Model version 4 $(\mathrm{CLM} 4)^{49}$ formulation of bulk canopy conductance as $R_{\mathrm{s}}=\frac{\mathrm{VPD}}{\mathrm{C}}$, where $R_{\mathrm{s}}$ is the canopy resistance.

Regional domains (shown in Fig. 2a) are as follows: North America $\left(20^{\circ} \mathrm{N}-58^{\circ}\right.$ $\left.\mathrm{N} ; 125^{\circ} \mathrm{W}-90^{\circ} \mathrm{W}\right)$; Amazon $\left(15^{\circ} \mathrm{S}-15^{\circ} \mathrm{N} ; 80^{\circ} \mathrm{W}-40^{\circ} \mathrm{W}\right)$; Eurasia $\left(28^{\circ} \mathrm{N}-55^{\circ} \mathrm{N}\right.$; $\left.10^{\circ} \mathrm{W}-95^{\circ} \mathrm{E}\right)$; South Africa $\left(35^{\circ} \mathrm{S}-15^{\circ} \mathrm{S} ; 12^{\circ} \mathrm{E}-38^{\circ} \mathrm{E}\right)$; Australia $\left(40^{\circ} \mathrm{S}-11^{\circ} \mathrm{S} ; 112^{\circ}\right.$ $\left.\mathrm{E}-155^{\circ} \mathrm{E}\right)$. Where area averages are presented, grid cells are weighted by the cosine of latitude.

Ensemble mean significance is estimated on the basis of two conservative criteria: $(1)$ a significant $(P<0.05)$ difference in the pooled model-year distribution in the historical period from that in the future period based on a KolmogorovSmirnov test and (2) at least $80 \%$ of models agree with the direction of ensemble mean change. We hatch regions with insignificant change. For significance of the time series at a particular time step (Fig. 2), we use a signal-to-noise ratio greater than $1(\mu / \sigma>1)$, relative to the beginning of the time series. Maps are produced using the 'MediumRes' base map in the National Center for Atmospheric Research (NCAR) Command Language (NCL) $)^{50}$

Following ref. ${ }^{25}$, we use a water budget of climatological WY precipitation balanced by the canopy (which is the sum of transpiration and leaf evaporation), runoff fluxes, a WY term that combines soil evaporation with aquifer and soil recharge and multi-year snow and canopy storage that is termed WY soil + storage. The land surface precipitation budget is written as $P=C+Q+S$, where $P$ is WY total precipitation, $C$ is WY total canopy water flux, $Q$ is WY total runoff and $S$ is WY soil evaporation and multi-year storage (soil + storage). To assess the potential BWT, we remove the change in precipitation allocated to $S$ and estimate the amount of change in precipitation the canopy should consume if partitioning were stationary. The difference between stationary partitioning and the actual partitioning is the BWT. See Mankin et al. ${ }^{31}$ for a full derivation of BWT.

Pooled model-year linear models for interannual partitioning of precipitation follow the form $\hat{Y}_{i r m}=\beta_{0}+\beta_{1} P_{i r m}+\beta_{2} T_{i r m}+\beta_{3} X+\epsilon_{i r m}$, where $\hat{Y}_{i r m}$ is one of the partitioning ratios $(C / P, Q / P$, or $S / P)$ in year $i$, region $r$ and model $m$, and $X$ is a set of categorical variables controlling for each model and region; $P$ is a WY total, $T$ is a WY average for each model and region, $\epsilon$ is the residual, and $\beta$ are the coefficients estimated by the regression (see Extended Data Fig. 4). The models skilfully predict interannual variations in partitioning in both the historical (1976-2005) and future (2070-2099) periods. Linear models for centennialscale changes (2070-2099 minus 1976-2005) in either runoff, $\Delta Q$, or canopy partitioning, $\Delta(C / P)$, are also estimated and do not include model and region controls as above; instead, the model is fit to account for the variability in the magnitude of change across the ensemble. For runoff across models and regions, we estimate the coefficients, $\beta$, in two forms, the first with just temperature and precipitation changes, $\widehat{\Delta Q_{r m}}=\beta_{0}+\beta_{1} \Delta P_{r m}+\beta_{2} \Delta T_{r m}+\beta_{3}\left(\Delta P_{r m} \times \Delta T_{r m}\right)+\epsilon_{r m}$, where $\Delta P_{r m} \times \Delta T_{r m}$ is an interaction term, and the second with the addition of the BWT as $\widehat{\Delta Q_{r m}}=\beta_{0}+\beta_{1} \Delta P_{r m}+\beta_{2} \Delta T_{r m}+\beta_{3}\left(\Delta P_{r m} \times \Delta T_{r m}\right)+\beta_{4} \mathrm{BWT}_{\mathrm{rm}}+\epsilon_{r m}$ (Extended Data Fig. 7). The addition of the BWT markedly increases the skill of the model to predict runoff changes
(Extended Data Fig. 7). For the $\Delta(C / P)$ model, we estimated it as $\Delta{\widehat{\left(\frac{C}{P}\right)_{r m}}}_{r} \beta_{0}+\beta_{1} \Delta \mathrm{LAI}_{\mathrm{rm}}+\beta_{2} \Delta\left(\frac{C}{\mathrm{ET}}\right)_{r m}+\beta_{3} \Delta P_{r m}+\beta_{4} \Delta T_{r m}+\beta_{5}\left(\Delta P_{r m} \times \Delta T_{r m}\right)+\epsilon$. See Extended Data Fig. 8. All regional-scale statistical analyses (correlation and regression) are performed with $\mathrm{R}(\mathrm{v} 3.2 .3)^{51}$

To constrain the CMIP5 ensemble projections of BWT and runoff change, we use the regional-scale observational mean and variability of the fraction of ET from the canopy (transpiration plus leaf evaporation, $C / E T$ ). Observations of $C / \mathrm{ET}$ are estimated as $(T+I) / \mathrm{ET}$ (where $I$ is canopy interception) from the dataset produced by Wei et al., which is a super ensemble of 108 permutations of observational sources ${ }^{32}$. The observational ranges for each region in Extended Data Fig. 9 are the mean \pm 1 s.d. across this super ensemble. To constrain BWT and runoff change, we use the relationship between present-day $C / \mathrm{ET}$ and future $C / P$, both at the regional scale (Extended Data Fig. 9). We average the models falling within the observational range for each region to update Fig. $4 \mathrm{~b}$, showing the observationally constrained ensemble mean (and standard error) BWT and runoff change for each region.

\section{Data availability}

All data supporting the findings of this study are freely available from the following locations: CMIP5 model data: https://pcmdi.llnl.gov.

\section{Code availability}

All code to reproduce the results of this study are available on reasonable request from the corresponding author.

\section{References}

44. Taylor, K. E., Stouffer, R. J. \& Meehl, G. A. An overview of CMIP5 and the experiment design. Bull. Am. Meteorol. Soc. 93, 485-498 (2012).

45. Riahi, K. et al. RCP $8.5-$ a scenario of comparatively high greenhouse gas emissions. Climatic Change 109, 33-57 (2011).

46. Gu, H., Zong, Z. \& Hung, K. C. A modified superconvergent patch recovery method and its application to large deformation problems. Finite Elem. Anal. Des. 40, 665-687 (2004).

47. Berg, A., Sheffield, J. \& Milly, P. C. D. Divergent surface and total soil moisture projections under global warming. Geophys. Res. Lett. 44, 236-244 (2017)

48. Cook, B. I., Mankin, J. S. \& Anchukaitis, K. J. Climate change and drought: from past to future. Curr. Clim. Change Rep. 4, 164-179 (2018).

49. Oleson, K. W. et al. Technical Description of Version 4.0 of the Community Land Model (CLM) Technical Note No. NCAR/TN-478+STR NCAR (Univ. Corporation for Atmospheric Research, 2010).

50. The NCAR Command Language v.6.6.2 (NCAR, 2019).

51. R Core Team R: A Language and Environment for Statistical Computing (R Foundation for Statistical Computing, 2017).

\section{Acknowledgements}

We thank the Earth System Grid Federation and their archiving of the Coupled Model Intercomparison Project (phase 5) data and N. Henderson and H. Liu for the data serving and computing support in the Division of Ocean and Climate Physics at LamontDoherty Earth Observatory of Columbia University. We also greatly appreciate Z. Wei for kindly sharing his ET partitioning data ${ }^{29}$. J.S.M. was funded by the Burke Research Initiation Award and the National Science Foundation award AGS-1243204, which also supported R.S. and J.E.S. Additional support for R.S. and J.E.S. was provided by National Science Foundation awards GS-1401400, AGS-1805490, AGS-1602581 and OISE-

1743738. B.I.C. was supported by the NASA Modeling, Analysis, and Prediction. A.P.W. was supported by National Science Foundation award AGS-1703029 and NASA award 16-MAP16-0081. Lamont contribution \#8359.

\section{Author contributions}

J.S.M., R.S., J.E.S., B.I.C. and A.P.W. conceived the study. J.S.M. designed and performed the analysis. All authors interpreted the results. J.S.M. wrote the manuscript with all authors providing critical input.

\section{Competing interests}

The authors declare no competing interests.

\section{Additional information}

Extended data is available for this paper at https://doi.org/10.1038/s41561-019-0480-x.

Supplementary information is available for this paper at https://doi.org/10.1038/ s41561-019-0480-X.

Correspondence and requests for materials should be addressed to J.S.M.

Peer review information Primary Handling Editor(s): Heike Langenberg.

Reprints and permissions information is available at www.nature.com/reprints. 


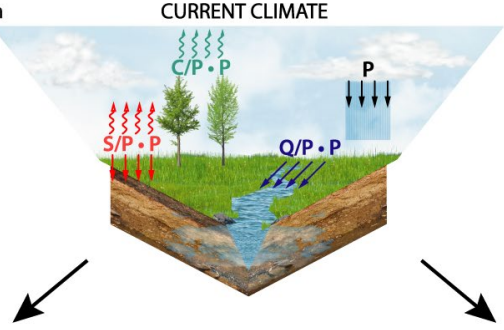

b

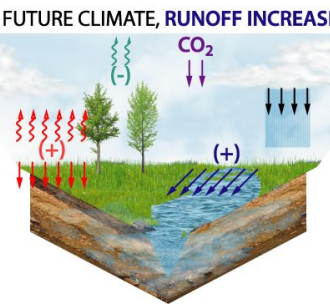

FUTURE CLIMATE, CANOPY INCREASE

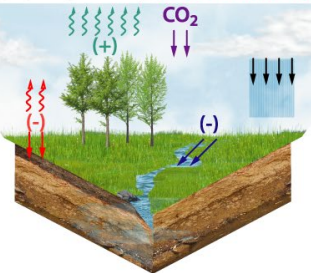

Extended Data Fig. 1 | Precipitation partitioning in the present and future. a., WY partitioning $[\mathrm{mm} / \mathrm{yr}]$ of precipitation $(\mathrm{P})$ among the canopy $(\mathrm{C} / \mathrm{P}$, green), runoff (Q/P, blue), and soil + storage (S/P, red), shown as fluxes in the current climate. All else equal, high $\left[\mathrm{CO}_{2}\right]$ and warming-induced $V P D$ could close stomata, decreasing transpiration and increasing soil water and runoff, as in $\mathbf{b}$. Soil water and runoff could alternatively decrease as longer and warmer growing seasons and $\mathrm{CO}_{2}$ fertilization increase ecosystem water demands, leading to reductions in soil water and runoff, as in $\mathbf{c}$. 


\section{NATURE GEOSCIENCE}
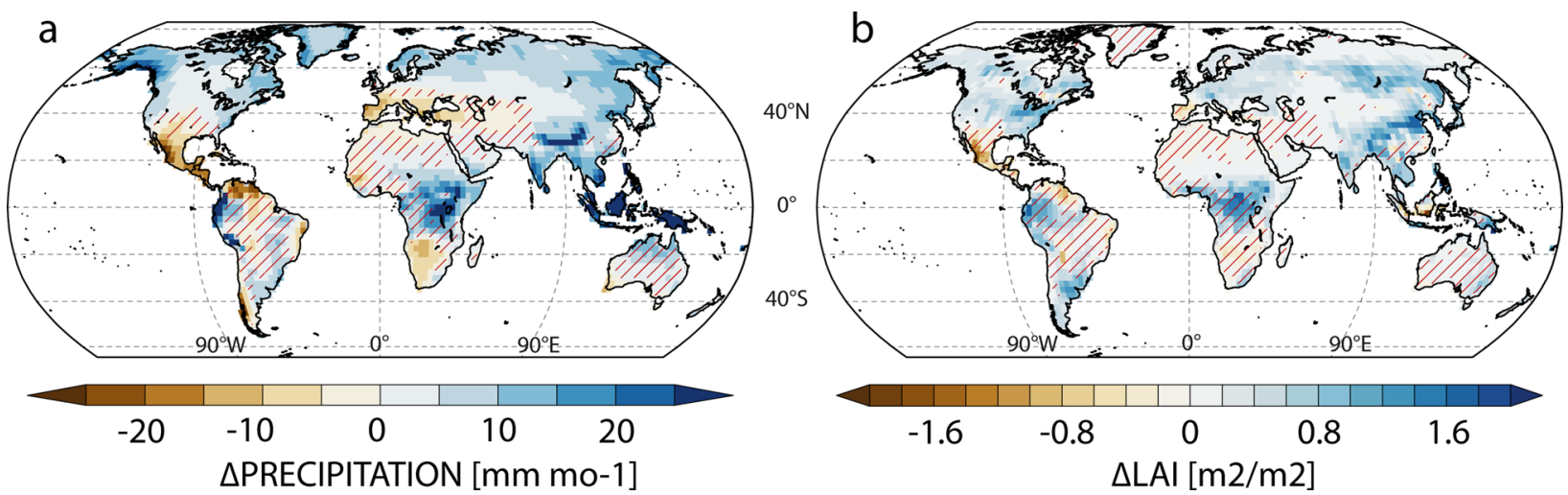

Extended Data Fig. 2 | Precipitation and leaf area index (LAI) changes. End-of-century changes in average a., WY precipitation ( $\mathrm{mm}$ mo-1) and $\mathbf{b}$., annual-scale leaf area index (LAI, unitless) for the ensemble mean. Red hatching indicates insignificant change based on a K-S test of the historical period (1976-2005) versus the future (2070-2099) and that at least $80 \%$ of the models agree on the direction of mean change at that point. 


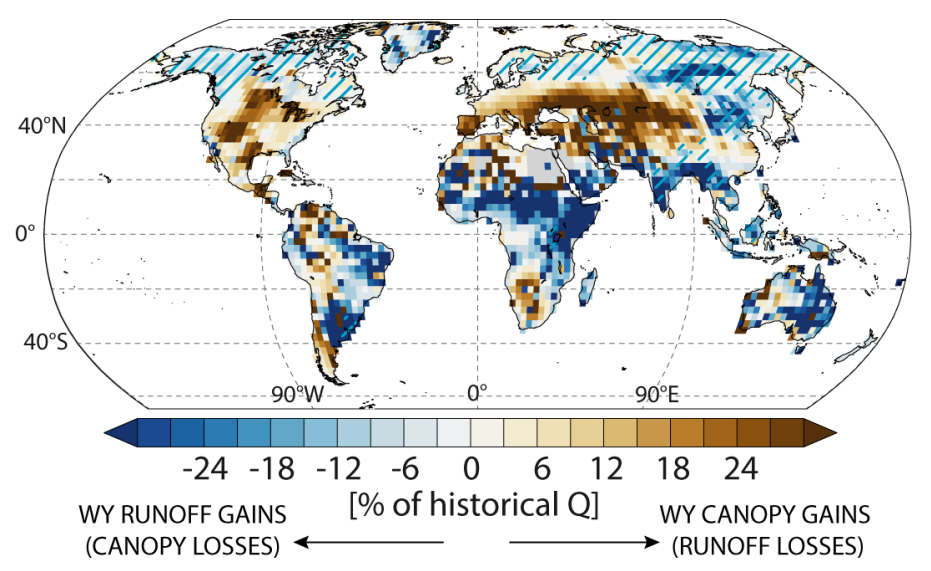

Extended Data Fig. 3 | Relative change in the Blue Water Tradeoff. As in Fig. 2a, but expressed as a fraction of historical WY runoff. 


\section{NATURE GEOSCIENCE}
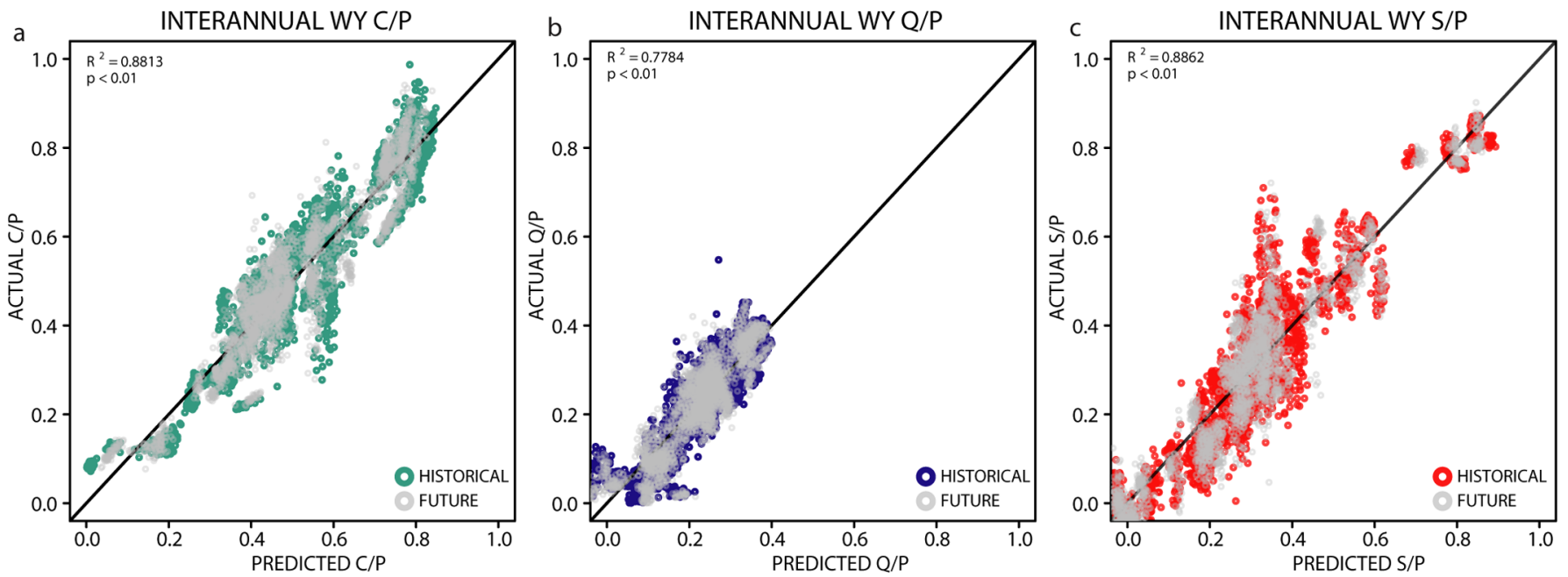

Extended Data Fig. 4 | Accounting for interannual variation in precipitation partitioning in the present and future. Performance of a statistical model of model- and region-based interannual WY (a) canopy partitioning, $C / P,(\mathbf{b})$ runoff partitioning $(\mathrm{Q} / \mathrm{P})$, (c) and soil + storage partitioning (S/P). In each panel, the partitioning predicted by the statistical model ( $\mathrm{x}$-axis) is plotted against its actual value as simulated by the CMIP5 models for each grid point in each region. Historical years (1976-2005) and future years (2070-2099) are shown. The statistical model for each partitioning ratio and period is the same: $Y=\beta 0+\beta 1^{\star}(W Y P)+\beta 2^{\star}(W Y T)+\beta 3^{\star}(<X>)$, where $Y$ is either $W Y C / P, W Y Q / P, W Y S / P$ and $<X>$ is a set of model and region control variables. The 1:1 line is shown in each panel. 


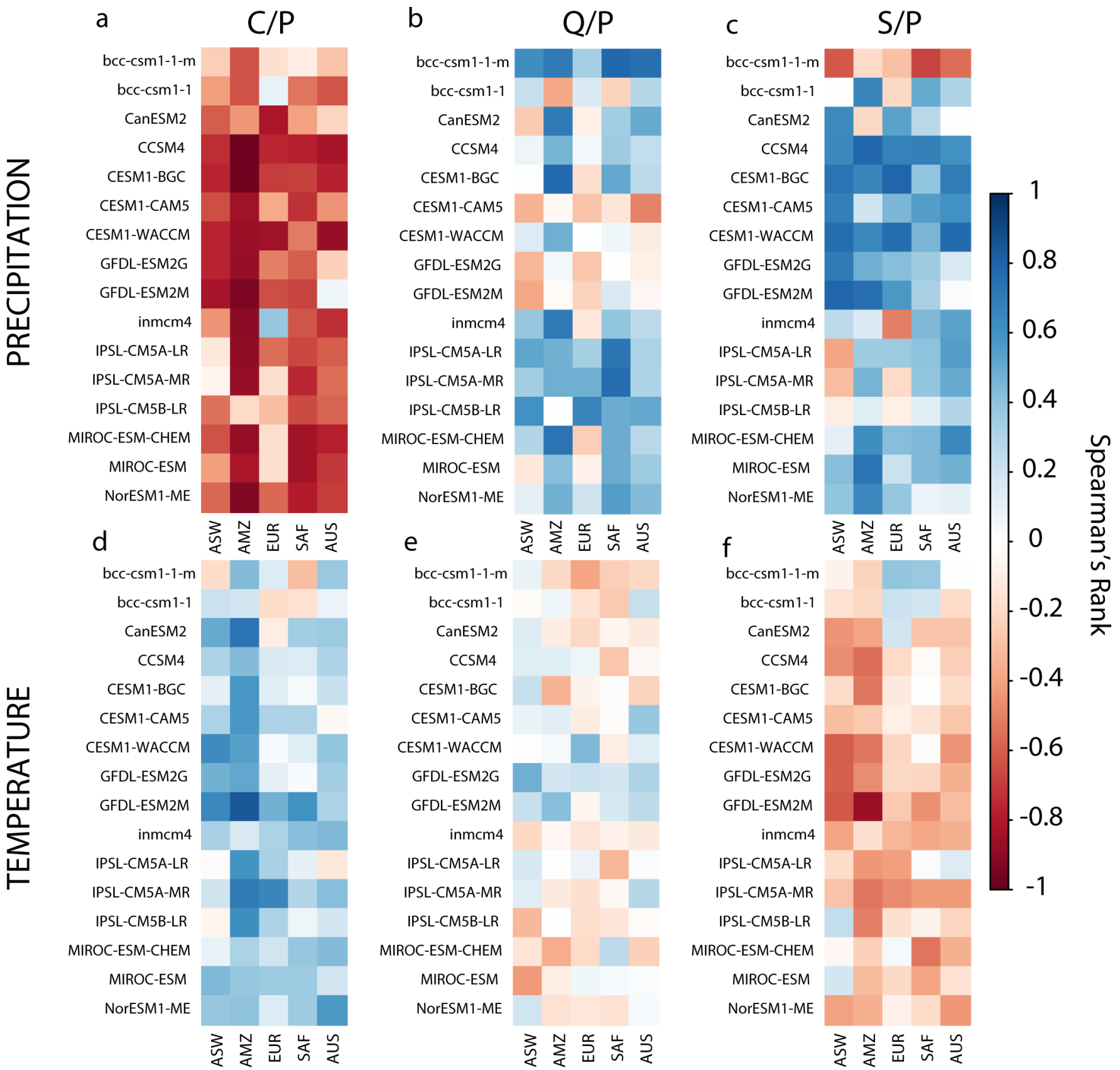

Extended Data Fig. 5 | Model-by-model correlations among partitioning, temperature, and precipitation. Model- and region-based Spearman's rank correlation of historical (1976-2005) partitioning ratios with historical precipitation (a-c) and temperature (d-f). 

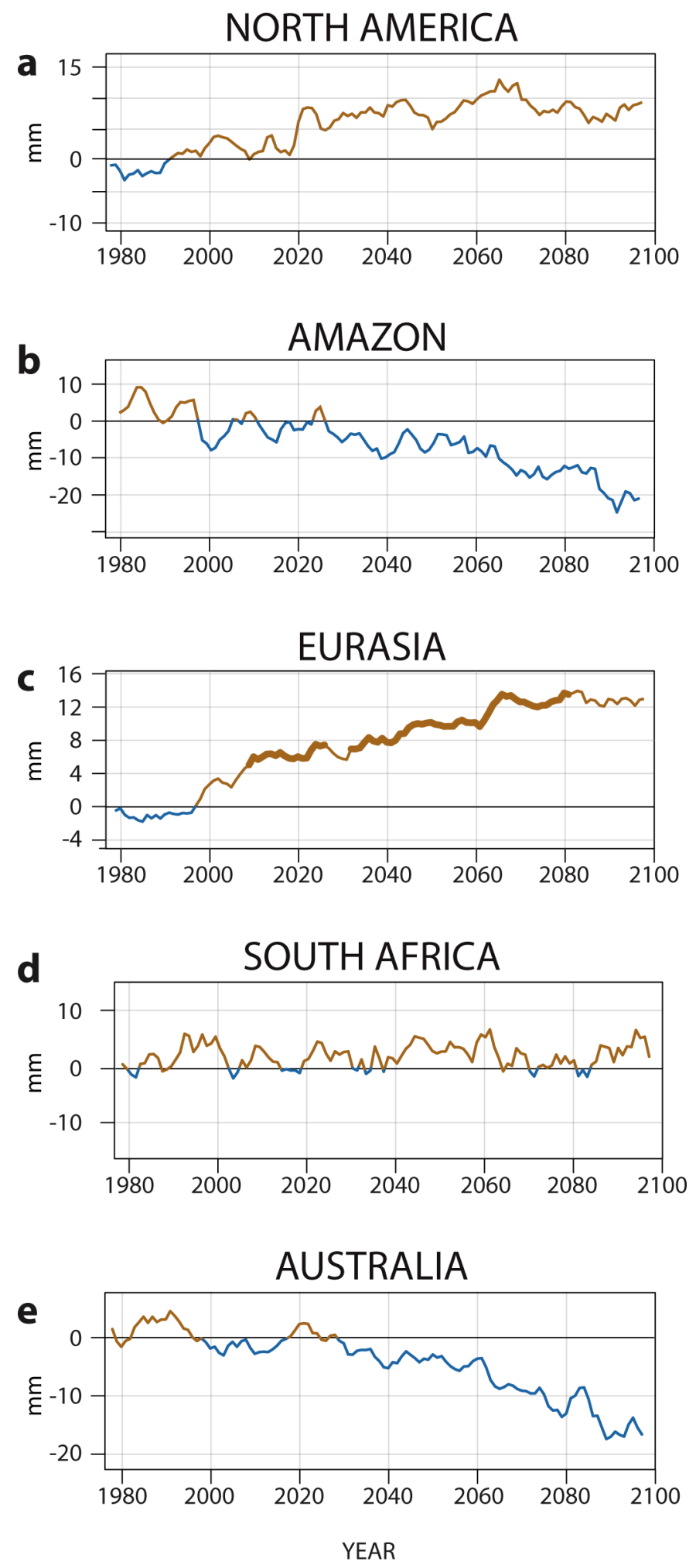

Extended Data Fig. 6 | Regional-scale blue water tradeoff time series. Ensemble mean time series in the runoff loss to the canopy, the blue water tradeoff (BWT) for the five regions as an anomaly from the 1976-2005 baseline. Positive (brown) values indicate the amount of WY precipitation going to the canopies to the sacrifice of runoff; negative (blue) values show the opposite. Bolded lines in each regional time series panel signify signal emergence ( $>1$ ) of the ensemble mean $(\mu / \sigma)$ in that year from the baseline (1976-2005). 
a

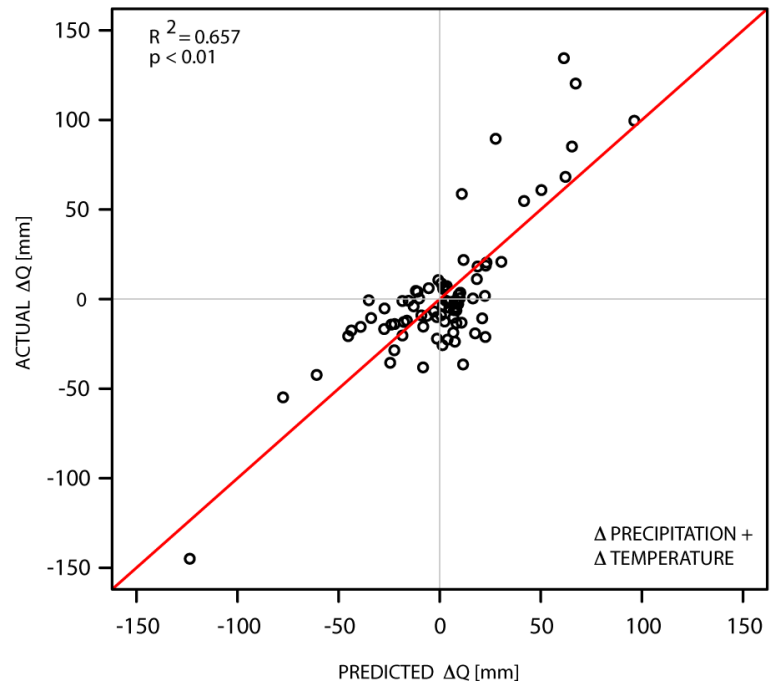

b

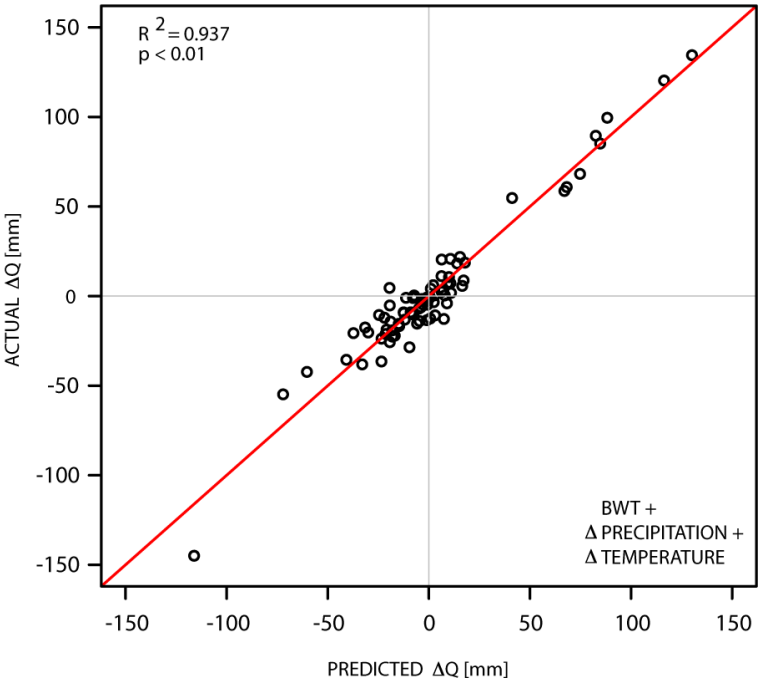

Extended Data Fig. 7 | BWT accounts for runoff changes. Performance of a statistical model of model- and region-based centennial-scale changes in WY runoff $(\Delta \mathrm{Q})$ without (a) and with (b) the canopy-runoff tradeoff (blue water tradeoff, BWT) metric. The model and region based $\Delta \mathrm{Q}$ predicted by the statistical model ( $\mathrm{x}$-axis) is plotted against its actual value as simulated by the CMIP5 models for each region. The statistical model for (a) includes temperature and precipitation and their interaction: $\Delta Q=\beta 0+\beta 1^{\star}(\Delta P)+\beta 2^{\star}(\Delta T)+\beta 3^{\star}\left(\Delta T^{\star} \Delta P\right)$. The statistical model for (b) adds the $B W T$ value for each model and region. The 1:1 line is shown in each panel. 


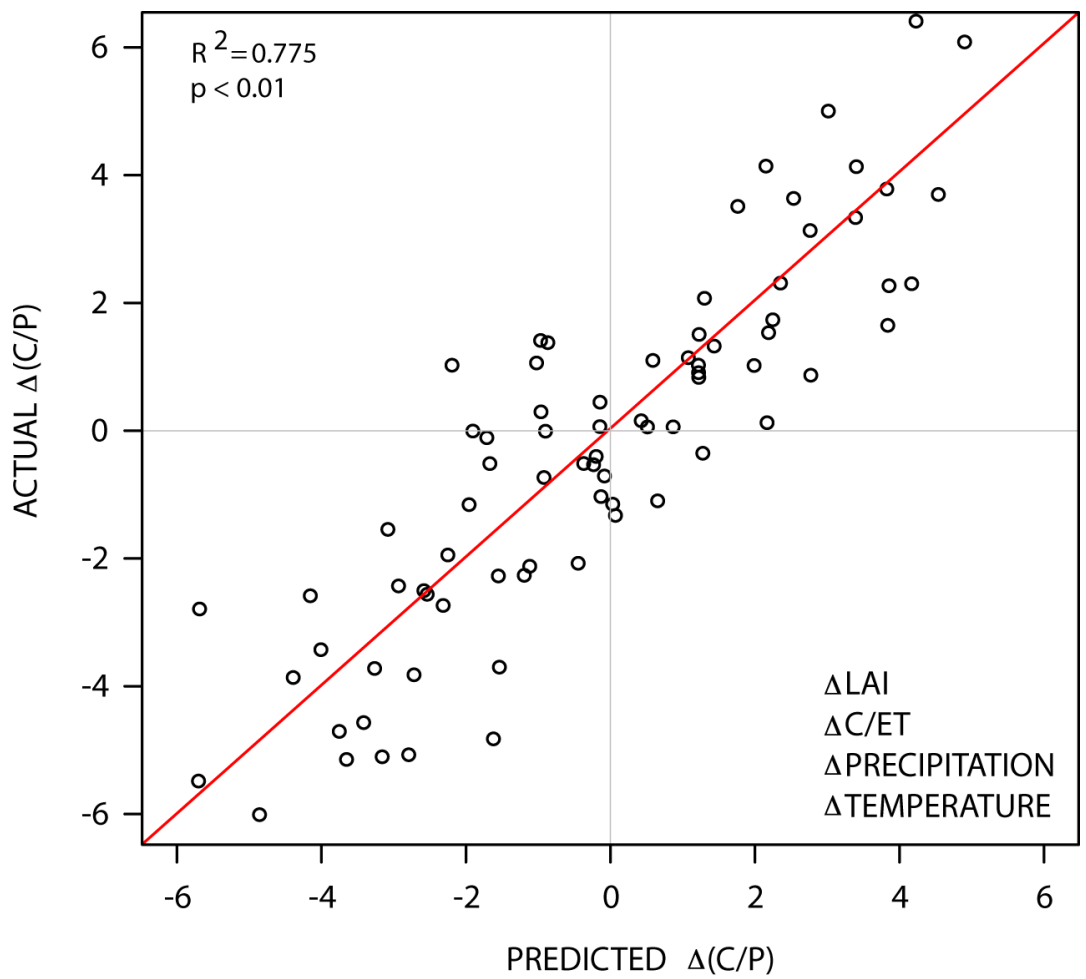

Extended Data Fig. 8 | Accounting for regional canopy partitioning changes. Performance of a statistical model of model- and region-based centennialscale changes in WY $C / P(\Delta(C / P))$. The $\Delta(C / P)$ predicted by the statistical model ( $x$-axis) is plotted against its actual value as simulated by the CMIP5 models for each region. The statistical model includes temperature and precipitation and their interaction: $\Delta \mathrm{Q}=\beta 0+\beta 1^{\star}(\Delta \mathrm{LAI})+\beta 2^{\star}(\Delta \mathrm{C} /$ $E T)+\beta 3^{\star}(\Delta P)+\beta 4^{\star}(\Delta T)+\beta 5^{\star}\left(\Delta P^{\star} \Delta T\right)$. The 1:1 line is shown. In the standardized version of this model (that is, $\left.\left(X-\mu_{x}\right) / \sigma_{x}\right)$, the coefficient of $\Delta(C / E T)$ is largest, twice that of $\Delta P$. 
a
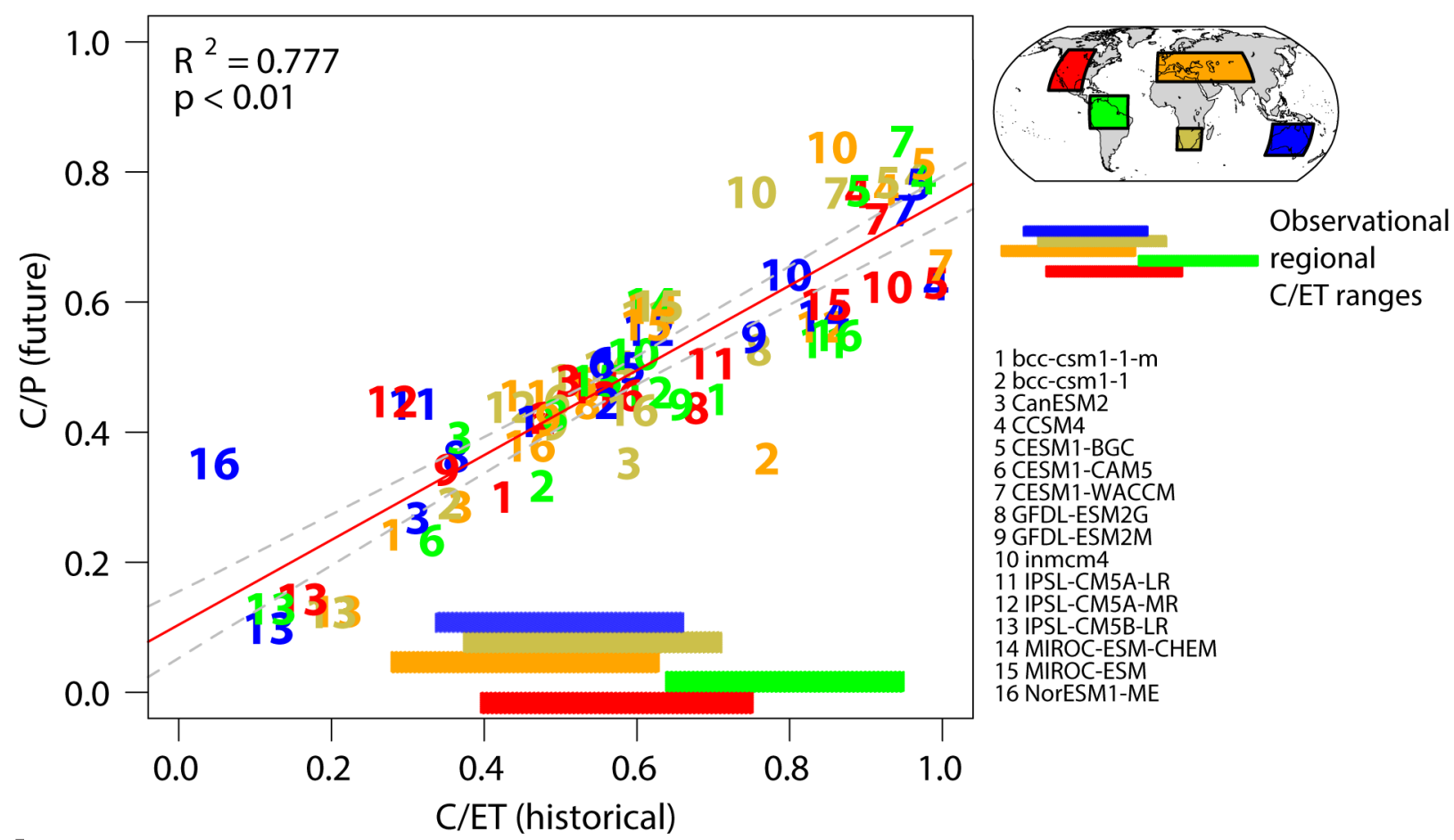

1 bcc-csm 1-1-m

2 bcc-csm 1-1

3 CanESM2

4 CCSM4

5 CESM1-BGC

6 CESM1-CAM5

7 CESM1-WACCM

8 GFDL-ESM2G

9 GFDL-ESM2M

10 inmcm4

11 IPSL-CM5A-LR

12 IPSL-CM5A-MR

13 IPSL-CM5B-LR

14 MIROC-ESM-CHEM

15 MIROC-ESM

16 NorESM1-ME

b

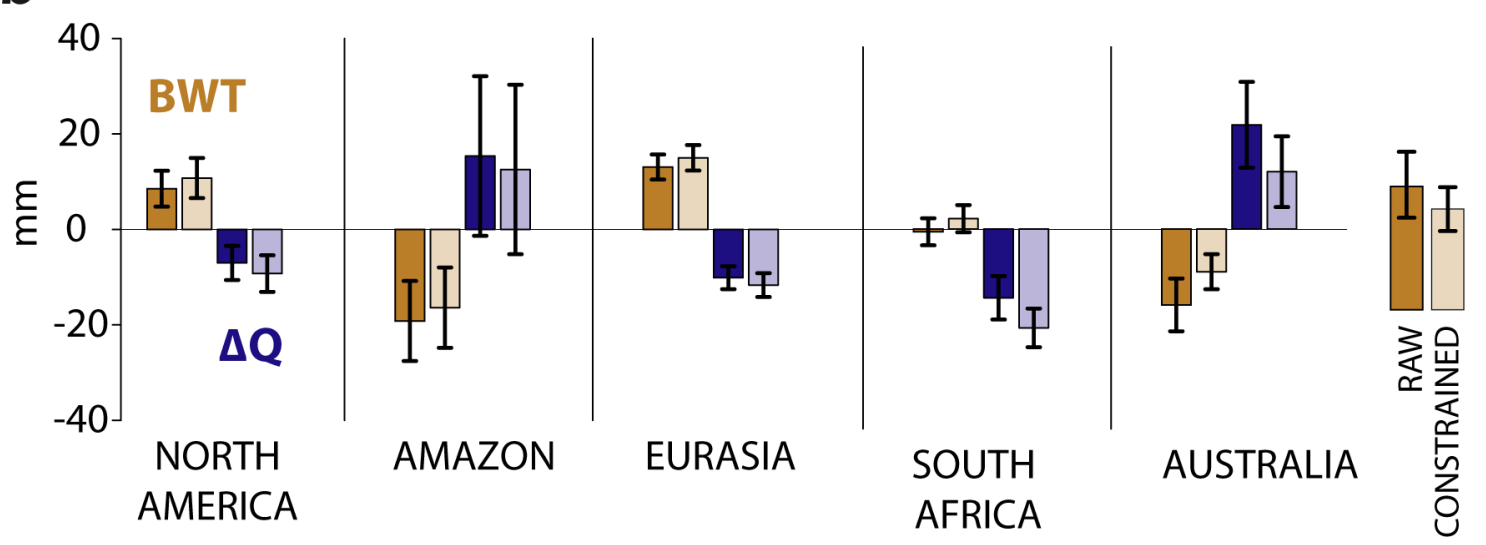

Extended Data Fig. 9 | Observational constraint for the blue water tradeoff. Constraining the runoff loss to vegetation (blue water tradeoff, BWT) and changes in runoff, $\Delta \mathrm{Q}$. Because $\Delta \mathrm{C} / \mathrm{ET}$ dominates changes in C/P (see Fig. S8), we show the relationship between historical (observed period, 19822014) $C / E T$ and future $C / P$ in (a) across models and regions. For each region, we show the observational range $(+/-1 \sigma)$ of $C / E T$, derived from the sum of interception and transpiration from Wei et al. GRL (2017) as colored bars mapping to the x-axis, with colors corresponding to the inset map. (b) Bar plot of unconstrained (raw) versus constrained BWT and $\Delta \mathrm{Q}$ for each region. Whiskers show 1 standard error of the mean. 
In the format provided by the authors and unedited.

\section{Mid-latitude freshwater availability reduced by projected vegetation responses to climate change}

Justin S. Mankin $\oplus^{1,2,3 \star}$, Richard Seager $\oplus^{3}$, Jason E. Smerdon ${ }^{3}$, Benjamin I. Cook ${ }^{3,4}$ and A. Park Williams ${ }^{3}$

'Department of Geography, Dartmouth College, Hanover, NH, USA. '2Department of Earth Sciences, Dartmouth College, Hanover, NH, USA. ${ }^{3}$ Lamont-Doherty Earth Observatory of Columbia University, Palisades, NY, USA. ${ }^{4}$ NASA Goddard Institute for Space Studies, New York, NY, USA.

*e-mail: mankin@dartmouth.edu 


\begin{tabular}{|c|c|c|c|c|c|c|c|c|c|c|}
\hline Region & $\begin{array}{l}\text { FACE site } \\
\text { (lat, lon) }\end{array}$ & $\begin{array}{l}\text { Vegetation } \\
\text { type }\end{array}$ & $\begin{array}{c}\mathrm{CO}_{2} / \\
\text { warming } \\
\text { treatment }\end{array}$ & $\begin{array}{l}\text { Treatment } \\
\text { years }\end{array}$ & $\begin{array}{c}\text { LAI } \\
\text { Trend } \\
\text { (consistent?) }\end{array}$ & $\begin{array}{c}\text { Transpiration } \\
\text { trend } \\
\text { (consistent?) }\end{array}$ & $\begin{array}{l}\text { Interception } \\
\text { trend } \\
\text { (consistent?) }\end{array}$ & $\begin{array}{c}\text { Soil moisture } \\
\text { trend } \\
\text { (consistent?) }\end{array}$ & $\begin{array}{c}\text { Runoff } \\
\text { trend } \\
\text { (consistent?) }\end{array}$ & $\begin{array}{c}\text { Assessed } \\
\text { consistency } \\
\text { with CMIP5 }\end{array}$ \\
\hline \multirow[t]{7}{*}{$\begin{array}{l}\text { (1) NORTH } \\
\text { AMERICA }\end{array}$} & $\begin{array}{c}\text { Rhinelander } \\
(45.36,89.42)\end{array}$ & Deciduous & $\begin{array}{l}\text { Ambient } \\
+200 \mathrm{ppm}\end{array}$ & 1997-2009 & $\begin{array}{c}\text { increase }^{1,2} \\
(\text { yes })\end{array}$ & $\begin{array}{c}\text { increase }^{1-3} \\
\text { (yes) }\end{array}$ & 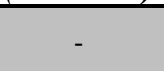 & $\begin{array}{l}\text { unchanged }^{2} \\
\text { (uncertain) }^{-}\end{array}$ & (2) & $\begin{array}{c}\text { uncertain } \\
\text { (no warming) }\end{array}$ \\
\hline & $\begin{array}{c}\text { BioCON } \\
(45.24,93.12)\end{array}$ & $\begin{array}{l}\text { Grassland } \\
\text { (C3/C4) }\end{array}$ & $550 \mathrm{ppm}$ & 1997-present & $\begin{array}{c}\text { slight } \\
\text { increase } \\
\text { (uncertain) }\end{array}$ & $\begin{array}{l}\text { decrease }^{4} \\
\text { (uncertain) }\end{array}$ & $\begin{array}{l}\text { increase }^{4} \\
\quad(y e s)\end{array}$ & $\begin{array}{l}\text { increase } 4,6 \\
\text { (uncertain) }\end{array}$ & $\begin{array}{c}\text { slight } \\
\text { increase }^{4} \\
\text { (uncertain) }\end{array}$ & $\begin{array}{l}\text { uncertain } \\
\text { (no warming) }\end{array}$ \\
\hline & $\begin{array}{l}\text { Duke FACE } \\
(35.58,79.5)\end{array}$ & $\begin{array}{l}\text { Needleleaf } \\
\text { evergreen }\end{array}$ & $550 \mathrm{ppm}$ & $1994-2010$ & $\begin{array}{l}\text { increase }^{7,8} \\
\text { (uncertain) }\end{array}$ & $\begin{array}{l}\text { uncertain }^{9,10} \\
\text { (uncertain) }\end{array}$ & - & $\begin{array}{l}\text { unchanged }^{10} \\
(y e s)\end{array}$ & $\begin{array}{c}\text { unchanged }^{10} \\
\text { (yes) }\end{array}$ & $\begin{array}{c}\text { uncertain } \\
\text { (no warming) }\end{array}$ \\
\hline & $\begin{array}{c}\text { Jasper Ridge } \\
(37.24 \\
122.14)\end{array}$ & Grassland & $\begin{array}{l}2 \mathrm{x} \text { ambient } \\
\text { +warming }\end{array}$ & 1997-present & - & - & - & $\begin{array}{l}\text { increase }^{11} \\
\text { (no) }\end{array}$ & - 0 & no \\
\hline & $\begin{array}{c}\text { Nevada Desert } \\
(36.46 \\
115.57)\end{array}$ & Shrubland & $\begin{array}{l}\text { Ambient } \\
+50 \%\end{array}$ & $1997-2007$ & $\begin{array}{c}\text { slight } \\
\text { increase }{ }^{12,13} \\
\text { (yes) }\end{array}$ & $\begin{array}{c}\text { decrease }^{14} \\
(n o)\end{array}$ & - & $\begin{array}{c}\text { decrease }^{14} \\
(\text { yes })\end{array}$ & - & $\begin{array}{l}\text { uncertain } \\
\text { (no warming) }\end{array}$ \\
\hline & $\begin{array}{c}\text { ORNL } \\
(35.54,84.20)\end{array}$ & $\begin{array}{l}\text { Deciduous } \\
\text { broadleaf }\end{array}$ & $550 \mathrm{ppm}$ & 1998-2009 & $\begin{array}{c}\text { slight } \\
\text { increase } e^{4,15} \\
(y e s)\end{array}$ & $\begin{array}{c}\text { decrease }{ }^{4,9,16} \\
(n o)\end{array}$ & - & $\begin{array}{l}\text { increase }^{4} \\
\quad(\text { no })\end{array}$ & $\begin{array}{l}\text { slight } \\
\text { increase } e^{4} \\
\text { (no) }\end{array}$ & $\begin{array}{c}\text { no } \\
\text { (no warming) }\end{array}$ \\
\hline & $\begin{array}{c}\text { KSC } \\
(28.38,80.42)\end{array}$ & $\begin{array}{l}\text { Evergreen } \\
\text { shrub }\end{array}$ & $\begin{array}{l}\text { Ambient } \\
+350\end{array}$ & $1996-2007$ & $\begin{array}{c}\text { increase }^{15,17} \\
\text { (yes) }\end{array}$ & $\begin{array}{c}\text { decrease }^{18} \\
\text { (yes) }\end{array}$ & - & $\begin{array}{l}\text { increase }^{18} \\
\text { (no) }\end{array}$ & - & $\begin{array}{c}\text { no } \\
\text { (no warming) }\end{array}$ \\
\hline (2) AMAZON & $\begin{array}{l}\text { AmazonFACE } \\
\left(-2.6^{\circ},-60.2^{\circ}\right)\end{array}$ & $\begin{array}{l}\text { Broadleaf } \\
\text { evergreen }\end{array}$ & $\begin{array}{l}\text { Ambient } \\
+200 \mathrm{ppm}\end{array}$ & 2016-present & $\begin{array}{l}\text { modeled slight } \\
\text { increase }^{19} \\
(\text { yes })\end{array}$ & - & - & - & - & - \\
\hline $\begin{array}{l}\text { (3) SOUTH } \\
\text { AFRICA }\end{array}$ & - & - & - & - & - & - & - & - & - & - \\
\hline \multirow[t]{2}{*}{$\begin{array}{l}\text { (4) } \\
\text { AUSTRALIA }\end{array}$} & $\begin{array}{c}\text { EucFACE } \\
(-33.6,150.7)\end{array}$ & Dry evergreen & $550 \mathrm{ppm}$ & 2012-present & $\begin{array}{l}\text { uncertain }^{20} \\
\text { (uncertain) }\end{array}$ & $\begin{array}{c}\text { slight } \\
\text { increase }^{21} \\
\text { (uncertain) }\end{array}$ & $\begin{array}{l}\text { slight } \\
\text { increase }^{21} \\
\text { (uncertain) }\end{array}$ & $\begin{array}{c}\text { slight } \\
\text { decrease }^{21} \\
\text { (uncertain) }\end{array}$ & 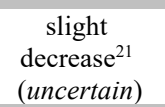 & $\begin{array}{l}\text { uncertain } \\
\text { (no warming) }\end{array}$ \\
\hline & $\begin{array}{c}\text { OzFace } \\
(-19,147)\end{array}$ & Grassland & up to $550 \mathrm{ppm}$ & 2001-present & - & - & - & - & - & - \\
\hline \multirow[t]{4}{*}{ (5) EURASIA } & $\begin{array}{c}\text { BIFoR-FACE } \\
(52.8,-2.3)\end{array}$ & $\begin{array}{l}\text { Temperate } \\
\text { deciduous }\end{array}$ & $550 \mathrm{ppm}$ & 2016-present & - & - & - & - & - & - \\
\hline & $\begin{array}{c}\text { PopEuro- } \\
\text { FACE } \\
(42.22,11.48)\end{array}$ & Deciduous & $550 \mathrm{ppm}$ & $1999-2001$ & $\begin{array}{l}\text { increase }^{22} \\
\text { (yes) }\end{array}$ & $\begin{array}{l}\text { decrease }^{22} \\
\text { (uncertain) }\end{array}$ & - & - & - & $\begin{array}{l}\text { uncertain } \\
\text { (no warming) }\end{array}$ \\
\hline & $\begin{array}{c}\text { GiFACE } \\
(50.32,8.4)\end{array}$ & Grassland & $\begin{array}{l}\text { Ambient } \\
+20 \%\end{array}$ & 1998-present & $\begin{array}{c}\text { slight } \\
\text { increase }^{23} \\
\text { (yes) }\end{array}$ & - & - & $\begin{array}{l}\text { increase }^{23} \\
\text { (no) }\end{array}$ & - & $\begin{array}{c}\text { no } \\
\text { (no warming) }\end{array}$ \\
\hline & $\begin{array}{l}\text { Web FACE } \\
(47.2,7.30)\end{array}$ & $\begin{array}{l}\text { Temperate } \\
\text { deciduous }\end{array}$ & $500 \mathrm{ppm}$ & 2000-2004 & $\begin{array}{l}\text { uncertain }^{24,25} \\
\text { (uncertain) }\end{array}$ & $\begin{array}{c}\text { slight } \\
\text { decrease } \mathrm{e}^{26,27} \\
\text { (uncertain) }\end{array}$ & - & $\begin{array}{c}\text { slight } \\
\text { increase }{ }^{26} \\
\text { (no) }\end{array}$ & $\begin{array}{l}\text { slight } \\
\text { increase }{ }^{26} \\
\text { (no) }\end{array}$ & $\begin{array}{c}\text { no } \\
\text { (no warming) }\end{array}$ \\
\hline
\end{tabular}

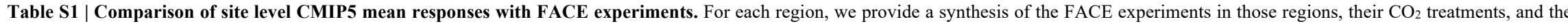
consistency or inconsistency (in parentheses) of FACE-derived trends in LAI, transpiration, interception, soil moisture, runoff, and across all quantities with the CMIP5 ensemble mean. Each site's FACE experiment response is compared against that same location in the ensemble mean from the CMIP5 models used in this study (see Fig. 2 in the main for the model list). The "Assessed Consistency with 
CMIP5" column provides an assessment of whether both the vegetation and hydrological responses from the FACE experiments are consistent or inconsistent with the changes at those locations in the ensemble mean of the CMIP5. We classify a study site as consistent ("yes"), if the CMIP5 ensemble mean of that quantity at that location is significant (Methods), and shares a trend direction that is consistent with the FACE experiment. If there is uncertainty in the CMIP5 at that location, we classify the consistency as "uncertain." A challenge is disentangling differences between leaf-level versus ecosystem leve responses, and the generalizability of the measurements, their treatments (e.g., nitrogen), and their experimental protocols. For example, many of the FACE experiments do not include warming in their protocols, making direct comparisons of transiently-forced, fully-coupled ESMs difficult. This is particularly the case, as only one study fully partitions ET into subcomponents as we do. This emphasizes the crucial importance of efforts like FACE-MDS to evaluate and constrain model uncertainty in vegetation-hydrological changes under both warming and increased [CO 2 in offline simulations forced with boundary conditions and protocols identical to the FACE experiments.

1. Karnosky, D. F. et al. Tropospheric O3 moderates responses of temperate hardwood forests to elevated CO2: A synthesis of molecular to ecosystem results from the Aspen FACE project. Funct. Ecol. 17, 289-304 (2003).

2. $\quad$ Uddling, J., Teclaw, R. M., Kubiske, M. E., Pregitzer, K. S. \& Ellsworth, D. S. Sap flux in pure aspen and mixed aspen-birch forests exposed to elevated concentrations of carbon dioxide and ozone. Tree Physiol. 28, 1231-1243 (2008)

3. Uddling, J., Teclaw, R. M., Pregitzer, K. S. \& Ellsworth, D. S. Leaf and canopy conductance in aspen and aspen-birch forests under free-air enrichment of carbon dioxide and ozone. Tree Physiol. 29, 1367-1380 (2009).

4. $\quad$ Cheng, L., Zhang, L., Wang, Y. P., Yu, Q. \& Eamus, D. Quantifying the effects of elevated CO2 on water budgets by combining FACE data with an ecohydrological model. Ecohydrology 7, 1574-1588 (2014).

5. Crous, K. Y., Reich, P. B., Hunter, M. D. \& Ellsworth, D. S. Maintenance of leaf N controls the photosynthetic CO2 response of grassland species exposed to 9 years of free-air CO2 enrichment. Glob. Chang. Biol. 16, 2076-2088 (2010).

6. Adair, E. C., Reich, P. B., Trost, J. J. \& Hobbie, S. E. Elevated CO 2 stimulates grassland soil respiration by increasing carbon inputs rather than by enhancing soil moisture. Glob. Chang. Biol. 17, 3546-3563 (2011).

7. Mccarthy, H. R. et al. Temporal dynamics and spatial variability in the enhancement of canopy leaf area under elevated atmospheric CO2. Glob. Chang. Biol. 13, 2479-2497 (2007).

8. Schäfer, K. V. R., Oren, R., Lai, C. T. \& Katul, G. G. Hydrologic balance in an intact temperate forest ecosystem under ambient and elevated atmospheric CO2 concentration. Glob. Chang. Biol. 8, 895-911 (2002).

De Kauwe, M.

10. Ward, E. J. et al. Evapotranspiration and water yield of a pine-broadleaf forest are not altered by long-term atmospheric [CO2] enrichment under native or enhanced soil fertility. Glob. Chang. Biol. 24, 4841-4856 (2018)

11. Zavaleta, E. S. et al. Plants reverse warming effect on ecosystem water balance. Proc. Natl. Acad. Sci. 100, 9892-9893 (2003)

12. Evans, R. D. et al. Greater ecosystem carbon in the Mojave Desert after ten years exposure to elevated CO2. Nat. Clim. Chang. 4, 394-397 (2014).

13. Newingham, B. A. et al. No cumulative effect of 10 years of elevated [CO2] on perennial plant biomass components in the Mojave Desert. Glob. Chang. Biol. 19, 2168-2181 (2013).

14. Nowak, R. S. et al. Elevated atmospheric CO2 does not conserve soil water in the Mojave Desert. Ecology 85, 93-99 (2004).

15. Walker, A. P. et al. Decadal biomass increment in early secondary succession woody ecosystems is increased by CO 2 enrichment. Nat. Commun. 10, (2019).

16. Warren, J. M. et al. Ecohydrologic impact of reduced stomatal conductance in forests exposed to elevated CO2. Ecohydrology 4, 196-210 (2011).

17. Hungate, B. A. et al. Cumulative response of ecosystem carbon and nitrogen stocks to chronic CO2 exposure in a subtropical oak woodland. New Phytol. 200, 753-766 (2013).

18. Hungate, B. A. et al. Evapotranspiration and soil water content in a scrub-oak woodland under carbon dioxide enrichment. Glob. Chang. Biol. 8, 289-298 (2002).

19. Fleischer, K. et al. Amazon forest response to CO2 fertilization depend on plant phosphorus acquisition. Nat. Geosci. (2019). doi:10.1038/s41561-019-0404-9 
Duursma, R. A. et al. Canopy leaf area of a mature evergreen Eucalyptus woodland does not respond to elevated atmospheric [CO2] but tracks water availability. Glob. Chang. Biol. 22, 16661676 (2016).

21. Gimeno, T. E., McVicar, T. R., O’Grady, A. P., Tissue, D. T. \& Ellsworth, D. S. Elevated CO2 did not affect the hydrological balance of a mature native Eucalyptus woodland. Glob. Chang. Biol. 24, 3010-3024 (2018).

22. Liberloo, M. et al. Woody biomass production during the second rotation of a bio-energy Populus plantation increases in a future high CO 2 world. Glob. Chang. Biol. 12, 1094-1106 (2006).

23. Andresen, L. C. et al. Biomass responses in a temperate European grassland through 17 years of elevated CO2. Glob. Chang. Biol. 24, 3875-3885 (2018).

24. Bader, M. K. F., Siegwolf, R. \& Körner, C. Sustained enhancement of photosynthesis in mature deciduous forest trees after 8 years of free air CO2 enrichment. Planta 232, 1115-1125 (2010).

25. Korner, C. et al. Carbon Flux and Growth in Mature Deciduous Forest Trees Exposed to Elevated CO2. Science 309, 1360-1362 (2005).

26. Leuzinger, S. \& Körner, C. Rainfall distribution is the main driver of runoff under future CO2-concentration in a temperate deciduous forest. Glob. Chang. Biol. 16, 246-254 (2010).

27. Keel, S. G., Pepin, S., Leuzinger, S. \& Körner, C. Stomatal conductance in mature deciduous forest trees exposed to elevated CO2. Trees - Struct. Funct. 21, 151-159 (2007). 